\title{
JUSTIÇA TRIBUTÁRIA NO BRASIL: CONTEXTO SOCIAL E APLICABILIDADE JUDICIÁRIA
}

\author{
TAX JUSTICE IN BRAZIL: SOCIAL CONTEXT AND JUDICIAL APPLICABILITY
}

\section{Rayneider Brunelli Oliveira Fernandes ${ }^{1}$}

\begin{abstract}
RESUMO: O fenômeno da tributação é intrinsecamente complexo, pois envolve questões políticas, filosóficas, econômicas, jurídicas, sociológicas e psicólogicas. No Direito, questiona-se a eficácia dos princípios ligados à justiça tributária atribuída pelos tribunais. Nesse esteio, procurou-se, pelo procedimento de pesquisa bibliográfico e documental, evidenciar o contexto político-econômico de aplicação dos princípios tributários relacionados à justiça, bem como apresentar o desafio de efetivação da Constituição de 1988 nessa área. A partir do método hipotético-dedutivo, defende-se a permanente realização de reflexões críticas para o desenvolvimento do papel do Judiciário de fiscalização da atuação dos poderes constituídos na relação jurídica (historicamente de poder) entre o fisco e o contribuinte.
\end{abstract}

PALAVRAS-CHAVE: Justiça tributária. Igualdade. Judiciário. Direitos fundamentais.

\begin{abstract}
The taxation phenomenon is inherently complex, because it involves political, philosophical, economic, legal, sociological and psychological issues. In law, it questions the effectiveness of the principles related to tax justice assigned by the courts. In this pillar, it attempted to highlight, through the bibliographical and documental research, the political and economic context of application of tax principles related to justice and to present the challenge of granting effectiveness to the braziliian Constitution. By the hypothetical-deductive method, it is defended the permanent achievement of critical reflections on the development of the Judicial's oversight role of the actions of the powers in the juridical (historically of power) relationship between authorities and the taxpayer.
\end{abstract}

KEY-WORDS: Tax Justice. Equality. Judiciary. Fundamental rights.

\section{INTRODUÇÃO}

\footnotetext{
${ }^{1}$ Universidade Federal de Uberlândia. Graduado em Direito pela Universidade Federal de Ouro Preto. Mestre em Direito Público pela Universidade Federal de Uberlândia. Servidor do Tribunal Regional Federal da $4^{a}$ Região, na Seção Judiciária do Estado do Paraná. E-mail: rayneider@yahoo.com.br
} 
O tema da justiça fiscal no Brasil apresenta um longínquo histórico de resistência do sistema político à perpetração de reformas legislativas movidas pelo critério da progressividade, e de recalcitrância do Judiciário à concretização da igualdade na repartição das cargas públicas.

Diante disso, rastreiam-se problemas estruturais no sistema jurídico tributário, como excesso de obrigações acessórias, regressividade na distribuição do peso dos tributos e baixo retorno social da arrecadação.

A demolição da democracia em 1964 determinou em muito a quase inexistência de cidadania tributária no país e o distanciamento das políticas tributárias das teorias sobre justiça. No período da ditadura militar, principalmente a partir dos anos 1970, com o esforço pela industrialização e pela substituição de importações, o apelo à tributação progressiva perdeu força e o objetivo da tributação moveu-se da equidade à estabilização e ao crescimento (TANZI, 2013, p. 4).

Sabe-se que a ditadura não se sustentou no tempo; as crises econômica, de legitimidade e de matriz organizacional do Estado abriram caminho para que o Brasil fosse finalmente redemocratizado em 1988. Nesse contexto, encampou-se nova variável política e ideológica (GRECO, 2011, p. 9-18), lançando luzes para o reconhecimento da solidariedade como fundamento último da tributação e para a assunção da perspectiva democrática como arena apropriada para construção de soluções socioeconômicas arrojadas.

O Direito não passa infenso a essa mutação política; de forma gradual, estão sendo transmudados os modos de juridicidade e tenta-se substituir os critérios de racionalidade formal por uma práxis decisória mais orientada pela racionalidade substantiva (FARIA; CAMPILONGO, 1991, p. 21). Logicamente, problemas como o anacronismo e a diacronia no conjunto das normas jurídicas remanesceram; mas o resgate do Estado de Direito, nele embutida a defesa das franquias democráticas, propiciou, enfim, fazer do Judiciário estrutura politicamente neutralizada com função nuclear no sistema jurídico.

A pergunta que se pretende responder neste trabalho é a seguinte: Quais são os fundamentos da aplicação judicial dos princípios jurídico-tributários que constituem aspectos parciais de justiça? 
A presente pesquisa teórica filia-se à vertente jurídico-sociológica, trabalhando simultaneamente com as noções de eficiência (preocupação central da dogmática), eficácia e de efetividade das relações Direito/sociedade. Preocupa-se com a factidade do Direito e com as interações contraditórias que o próprio Direito estabelece com os demais campos ( $C f:$ GUSTIN; DIAS, 2013, p. 22), como a política e a economia. Utilizando o método hipotético-dedutivo, na investigação, prevalece o tipo jurídico-compreensivo, decompondo o objeto de pesquisa em vários níveis ( $C f$. LAKATOS; MARCONI, 1992, p. 106).

Além de apresentar um diagnóstico do quadro político-econômico referente à distribuição da carga fiscal; pretende-se, com o trabalho, proceder a um estudo crítico dos princípios constitucionais relacionados à justiça tributária na literatura especializada para rastrear, no âmbito na jurisprudência dos tribunais superiores no período pós-1988, os elementos de informação que permitam indicar com precisão o tratamento que se tem dispensado aos princípios constitucionais tributários ligados à justiça.

A proposta é justificada pela frustração que atualmente caracteriza a realização judicial dos princípios constitucionais ligados à justiça tributária ${ }^{2}$, percebendo-se haver, nesse foro, análises insuficientes e contradições em relação ao objeto de estudo.

O trabalho é dividido em quatro partes. Na primeira parte, têm-se como propósito específico evidenciar o protagonismo da isonomia para a concretização do ideal de justiça fiscal. No segundo capítulo, através de análise fundamentalmente documental e descritiva, expõem-se os indicadores que delineiam as especificidades político-econômicas da tributação no Brasil.

Em seguida, foca-se a realização jurisdicional da justiça tributária através da perscrutação da força obrigacional reconhecida pelos tribunais aos princípios constitucionais tributários. Por fim, adotando como referencial a teoria dos sistemas (Cf:: LUHMANN, 2009, 414 p.), constróise hipótese consistente na afirmação do papel constitucional realístico do Judiciário, tendo em vista a sua limitada capacidade cognitiva (especialização funcional) para apreender fatos, interesses e valores como se dão no ambiente.

2 Por exemplo, o princípio da capacidade contributiva tem sido analisado sob uma perspectiva acessória, servindo mais como argumento anexo à violação de outros princípios. $C f$.: BRASIL, Supremo Tribunal Federal. RE n. 72.400/RN Primeira Turma. Relator Min. Barros de Monteiro. In: DJ de 26.11.1971. 


\section{JUSTIÇA FISCAL E PRINCÍPIO DA IGUALDADE}

O Estado fiscal ergueu-se no dever fundamental de pagar tributos fundados na solidariedade social. E a igualdade na distribuição das cargas públicas, como princípio regulador desse dever, é reivindicação que até hoje apresenta dificuldades de concretização³.

\subsection{Escorço histórico da legislação tributária brasileira}

O Direito Tributário é recente como área de conhecimento sistematizado, tendo-se como referencial histórico o Código Tributário Alemão de 1919. No Brasil, só na década de quarenta que o tributo passou a ser objeto de preocupação científica em separado do bojo da Ciência das Finanças (GRECO, 2011, p. 9-18). Desde então, construiu-se uma concepção de Direito Tributário como "[...] conjunto de normas protetivas do patrimônio individual e limitadoras das investidas do Fisco" (MACHADO, 2004, p. 60).

Na década de setenta, a obra de Geraldo Ataliba (1993, p. 45-125) trouxe para a esfera tributária os âmbitos kelsenianos de validade da norma na forma de "aspectos" (material, pessoal, temporal, quantitativo e espacial) da hipótese de incidência (=previsão abstrata) do tributo. À formulação de Ataliba, Tércio Sampaio Ferraz Júnior (1993, 205 p.) aportou suas lições oriundas da semiótica, introduzindo no debate questões dos planos da linguagem (sintático, semântico e pragmático). Porém, discussões de caráter substancial, sobre isonomia, capacidade contributiva, distorções concorrenciais e funções do Estado, ficaram em segundo plano (GRECO, 2011, p. 9-18).

Alberto Xavier (1978, p. 92), influenciado pela metodologia de Karl Larenz (1997, p. 490), afirmava que a tipicidade do Direito Tributário seria fechada: "contém em si todos os

\footnotetext{
3 Este trabalho utiliza-se, em parte relevante, da análise bibliográfica realizada por ocasião do desenvolvimento da dissertação de mestrado, trabalho cujo objeto referia-se ao controle judicial de validade da extrafiscalidade. $C f$ : : FERNANDES, Rayneider Brunelli de Oliveira. Controle da extrafiscalidade à luz da igualdade: limitações ao poder de desonerar e soluções jurisdicionais para correção de situações anti-isonômicas. Dissertação (mestrado) - Universidade Federal de Uberlândia, Programa de Pós-Graduação em Direito. 2014.183 f.
} 
elementos para a valoração dos efeitos, sem carecer de qualquer recurso a elementos a ela estranhos e sem tolerar qualquer valoração que se substitua ou acresça à contida no tipo legal”.

O tipo, ordenação dos dados concretos existentes na realidade segundo critérios de semelhança, superpõe-se à mera representação abstrata de dados empíricos (conceito), pois descreve a média ou a normalidade da situação concreta, com suas conexões de sentido (TORRES, 2006, p. 8). Predomina hoje que ele é fluído e aberto (DERZI, 1988, 398 p.); não tendo o feito de esgotar-se a aplicação do Direito Tributário no conceito fechado.

A Constituição de 1988 encampou nova variável política e ideológica (GRECO, 2011, p. 9-18), abrindo espaço para o reconhecimento da solidariedade como fundamento último da tributação e o para o ingresso do Direito Tributário na jurisprudência dos valores (TORRES, 2003, p. 90-123). É neste contexto que os debates finalmente encontram terreno fértil para ir além dos limites formais à atuação do legislador e abarcar questões como a coerência e a justiça da carga fiscal.

A adequação do fato gerador concreto no plano abstrato pode fazer-se pela subsunção, pela discricionariedade (para interpretar conceitos indeterminados) e pela tipificação (formação normativa do tipo). A regra de incidência tributária compõe-se de conceitos determinados, conceitos indeterminados, cláusulas gerais e tipos. Assim, embora a tipificação sirva à segurança jurídica, ela, como técnica de adequação do fato à norma, deve ser ponderada com os princípios derivados da justiça tributária.

\subsection{Deveres fundamentais e tributação}

Todos os sistemas jurídicos impõem deveres fundamentais (MARTINS, 2013, p. 256), como o dever de pagar de impostos, sendo a tributação expressão da soberania estatal fundada na dignidade da pessoa humana (NABAIS, 2007, p. 1-24).

Nos escritos referentes às origens da tributação, ilustra-se a percepção da indispensabilidade de haurir recursos da coletividade. Victor Uckmar (2002, p. 14) conta uma história que se passa há seis mil anos atrás na Suméria - uma planície fértil entre os rios Tigre e 
Eufrates - onde atualmente é o Iraque. Alguns inscritos de argila encontrados em Lagash apontam o fato de que se aplicavam impostos para cobrir os gastos de uma terrível guerra, mas, uma vez que cessavam as hostilidades, os coletores de impostos pretendiam manter a exação. Esses inscritos também relatam que havia recolhedores de impostos em todos os lugares, com o fim de tributar qualquer evento ou coisa: os serviços funerários não podiam realizar-se se o defunto não houvesse pagado todos os impostos que devia. A truculência era tamanha que fora documentada a seguinte frase: "Você pode ter um Senhor, você pode ter um Rei, mas a quem o homem deve temer é o coletor de impostos". Esse regime terrorista terminou quando o rei Urukagina restaurou a liberdade eliminando aqueles que cobravam os tributos. Não obstante, a falta de recursos trouxe como resultado a derrota durante a invasão. A partir disso, passou-se a reconhecer o papel fundamental da aplicação de impostos para dispor de meios para a defesa ou ofensiva militar.

A fundamentabilidade dos deveres fundamentais é explicada por sua previsão constitucional (aspecto formal), explícita ou implícita, embora sejam detalhados e concretizados no nível infraconstitucional. Os deveres fundamentais são prescrições ligadas à vida econômica, social e cultural que assumem relevância constitucional (MIRANDA, 2005, p. 292). Uma noção material dos deveres fundamentais refere-se à posição da pessoa na sociedade, podendo ser caracterizados como posições jurídicas passivas (não ativas), autônomas (face aos direitos fundamentais), subjetivas, individuais (por ter como destinatários os indivíduos e só por analogia as pessoas coletivas), universais e permanentes (já que têm por base a universalidade ou a não discriminação) (NABAIS, 2007, p. 1-24).

Os deveres fundamentais não são cumpridos aleatoriamente, possuindo disciplina jurídica própria. Desse modo, ao regime jurídico dos deveres fundamentais que integram o estatuto constitucional da pessoa aplicam-se os seguintes princípios enumerados por José Casalta Nabais (2007, p. 1-24):

1) da universalidade ou da aplicação categorial, 2) da igualdade enquanto proibição do arbítrio, 3) da não discriminação em razão de critérios subjectivos ou de critérios interditos pela constituição como os que constam da lista, aliás bastante completa do art. $13^{\circ}, n^{\circ} 2$, da Constituição portuguesa, 4) da proporcionalidade nos três aspectos conhecidos (ou seja, da necessidade, da adequação e da proporcionalidade em sentido estrito) relativamente à sua concretização pelo legislador, 5) da aplicabilidade aos estrangeiros e apátridas, e 6) da tutela judicial. 
Nabais (2007, p. 1-24) ressalta que qualquer sociedade organizada está ancorada necessariamente em deveres fundamentais, que são justamente os custos lato sensu ou suportes da existência e funcionamento dessa mesma comunidade - "um empenho solidário de todos na transformação das estruturas sociais” (ANDRADE, 1987, p. 155). Embora não individualizável e parecer não exigir conduta comissiva estatal, o usufruto das liberdades pressupõe que a máquina estatal funcione para que ocorra sua proteção e realização (NABAIS, 2007, p. 1-24). Os direitos são custosos porque os remédios são custosos. "A aplicação é cara, especialmente a uniforme e razoável; e direitos legais são ocos na medida em que permanecem inaplicados" (HOLMES; SUNSTEIN, 2000, p. 43). Pode-se entrever, assim, que os direitos englobam mecanismos e procedimentos destinados a torná-los concretizáveis (MERON, 2004, p. 21).

\subsection{Da igualdade formal à igualdade proporcional}

Em sua primeira fase de reconhecimento, a igualdade correspondia à noção de que todos os homens são juridicamente iguais, não importando o conteúdo do tratamento e as circunstâncias pessoais. Esta perspectiva de matriz liberal da igualdade, de certo modo, satisfazia a exigência de generalidade e prevalência da lei (SARLET; MARINONI; MITIDIERO, 2012, p. 526-527).

Andrei Pitten Velloso (2010, p. 53) explica que o rechaço às propostas de se vincular a igualdade à justiça conduziu à sua antítese, que retira todo o conteúdo material do princípio da igualdade e nega a fórmula aristotélica de tratar desigualmente os desiguais na medida em que se desigualam. Essas teorias preconizam o caráter acessório da igualdade jurídica ou limitam-na a uma exigência de coerência sistêmica.

As teorias que defendiam o caráter acessório da igualdade negavam que uma lei pudesse ser declarada inconstitucional apenas com base nesse princípio. Para tanto, era necessário que houvesse alguma violação “[...] às cláusulas da interdição de discriminação ou aos princípios 
constitucionais democrático, do Estado de Direito, do Estado Social, do Estado Federal ou da separação de poderes" (VELLOSO, 2010, p. 54-55) ${ }^{4}$.

Para a teoria que adstringe a igualdade à exigência de coerência sistêmica, o princípio da igualdade é oco, sem qualquer conteúdo, sendo impossível extrair critérios constitucionais implícitos para sua concretização. Assim, outorga-se uma ampla margem de liberdade para o legislador escolher esses critérios, sem vinculação material ao princípio da igualdade ou a qualquer diretriz valorativa ${ }^{5}$, desde que se mantivesse a coerência interna nas estipulações das suas ações às premissas (VELLOSO, 2010, p. 55).

Outras concepções equiparam a igualdade à paridade de trato e negam a sua vinculação a exigências de tratamentos díspares. Nessa visão, a igualdade de trato atua como "presunção relativa", não como elemento conceitual da justiça, limitando o princípio a "uma simples carga argumentativa a favor dos tratamentos iguais", ou seja, se um tratamento desigual não puder ser justificado, então a justiça imporia o tratamento paritário. Assim, com essa fórmula, rechaçam-se os tratamentos diferenciados arbitrários. O problema dessa conceituação é que se limita a igualdade apenas ao mandamento de trato paritário, sem levar em conta valores constitucionais. Tal concepção revela-se eminentemente formal e absurda porque seria possível defender através dela uma igualdade tributária aritmética, por meio de um único "imposto por cabeças", ou ainda que o legislador suporte ônus argumentativo para estabelecer a carga tributária conforme a capacidade contributiva, e não o contrário (quando violá-la). Com razão, Andrei Velloso (2010, p. 56-58) diz os desvios perante a capacidade contributiva é que devem ser justificados e não a instituição de tributos que estejam em harmonia com esse critério.

Até 1980, o Tribunal Constitucional Federal alemão expressava o princípio da igualdade essencialmente por meio da fórmula da arbitrariedade. Esta concepção até então prevalente é agarrada à visão da igualdade como mandamento de tratamento paritário, flexibilizável somente

4 No Brasil, "foi somente com a Constituição de 1934 que a questão da isonomia começou a destacar-se do privilégio de nascimento, para abarcar outros critérios de diferenciação proibida de regime jurídico" (COMPARATO, Fábio Konder. Igualdade, Desigualdades. Revista Trimestral de Direito Público, São Paulo, n. 1: p. 69-78, 1993).

5 A ideia de que a igualdade exige como regra a uniformidade de tratamento é bastante difundida no Brasil. $C f$ : FERRAZ, Roberto Catalano Botelho. Igualdade na tributação: qual o critério que legitima as discriminações em matéria fiscal? In: FERRAZ, Roberto Catalano Botelho (coord.) Princípios e Limites da Tributação. São Paulo: Qurtier Latin, 2005, p. 453-520. 
quando respeitado o mandado de proporcionalidade (VELLOSO, 2010, p. 59-60) nos moldes da teoria de Robert Alexy (Cf:: ALEXY, 2008, p. 116-120).

Depois de muitas críticas, em 7 de outubro de 1980, o cenário mudou e foi concebida uma "nova fórmula" segundo a qual o princípio da igualdade é violado quando se dispensa tratamento a um grupo de destinatários normativos de maneira distinta da de outros destinatários normativos, embora entre ambos os grupos não exista diferenças de tal índole e de tal peso que possam justificar o tratamento desigual (VELLOSO, 2010, p. 59-60).

Andrei Pitten Velloso (2010, p. 60-61) critica essa nova fórmula por ser insuficiente ao não abarcar os tratamentos paritários, que também podem violar o princípio da igualdade, por se restringir aos tratos entre grupos de indivíduos e por não contemplar os tratamentos relativos a indivíduos isoladamente considerados ou a situações fáticas determinadas. Infelizmente, o Tribunal alemão ainda não admitiu a aplicação da fórmula inversa e equivalente à que proferiu (hipótese em que "se trata um grupo de destinatários normativos de forma igual a outros destinatários normativos, apesar de que entre ambos os grupos haja diferenças de tal índole e de tal peso que imponham um tratamento díspar"6). Contudo, para o âmbito tributário, pelo menos essa primeira limitação não repercute negativamente, posto que o trato de pessoas redundará, pelo caráter geral dos diplomas normativos, em trato de grupo de pessoas.

Fábio Konder Comparato (1993, p. 69-78) distingue isonomia (pressuposto da aplicação normativa concreta) da igualdade material (meta político-jurídica referente à igualdade de condições sociais). Percebe-se, nessa última visão a respeito da igualdade, que se pretende, parafraseando Marcelo Neves (2013, p. 30-31), pela atuação do princípio, imunizar o Direito da injunção de diferenças relevantes ao âmbito dos direitos. Com isso, trata-se de uma determinação contrafactual para neutralizar o Direito de pressões dessas diferenças. Na verdade, é mais do que isso porque se interessa também pela imposição de diferenças jurídicas, como no atendimento à capacidade contributiva, que são essenciais para a eficácia do princípio da igualdade: "Diferença não é sinônimo de desigualdade, assim como igualdade não é sinônimo de homogeneidade e de uniformidade" (SOARES, 2004, p. 62-63).

\footnotetext{
6 "Nem se poderia ser tratado o essencialmente igual como arbitrariamente desigual, nem o essencialmente desigual como arbitrariamente igual" (TIPKE, Klaus; LANG, Joachim. Direito tributário. Tradução de Luiz Doria Furquim.18. ed. Porto Alegre: Antonio Fabris Editor, 2008, p. 194).
} 


\subsection{Moral tributária}

“Por que as pessoas pagam tributos?” Respondendo a essa pergunta, Christian Daude, Guitiérrez e Melguizo (2013, p. 11-26) constatam que, num nível mais aprofundado, tributação e política fiscal estão no coração de todo contrato social. Cidadãos pagam tributos em troca de bens e serviços públicos. Ao mesmo tempo, essa troca legitima o equilíbrio político e o Estado. Entretanto, o link entre direitos e obrigações de diferentes atores é frequentemente fraco. Aspectos institucionais (como corrupção, transparência e responsabilidade do setor público) e psicológicos (como confiança e satisfação) impactam a arrecadação. Em pesquisa sobre a realidade latinoamericana, perguntou-se se "a sonegação pode ser justificável", se as pessoas sonegariam "se tivessem a oportunidade" e também se "bons cidadãos deveriam pagar tributos". O resultados para o delineamento da moral tributária na região são interessantes,: a) o medo de ser pego pelo fisco não se mostrou relevante; b) as pessoas que concebem a tributação como atividade com fins distributivos exibiram alta moral tributária; c) há um padrão de elencar a corrupção nas instituições estatais e a insatisfação com os serviços públicos para justificar a evasão fiscal. Na escala reproduzida abaixo, o Brasil, em 2010 (ano de elevados crescimento econômico e popularidade do governo central), entre os 18 países analisados, esteve em oitavo lugar no ranking de moralidade tributária: 
Figura 1: Índice de moralidade tributária na América Latina.

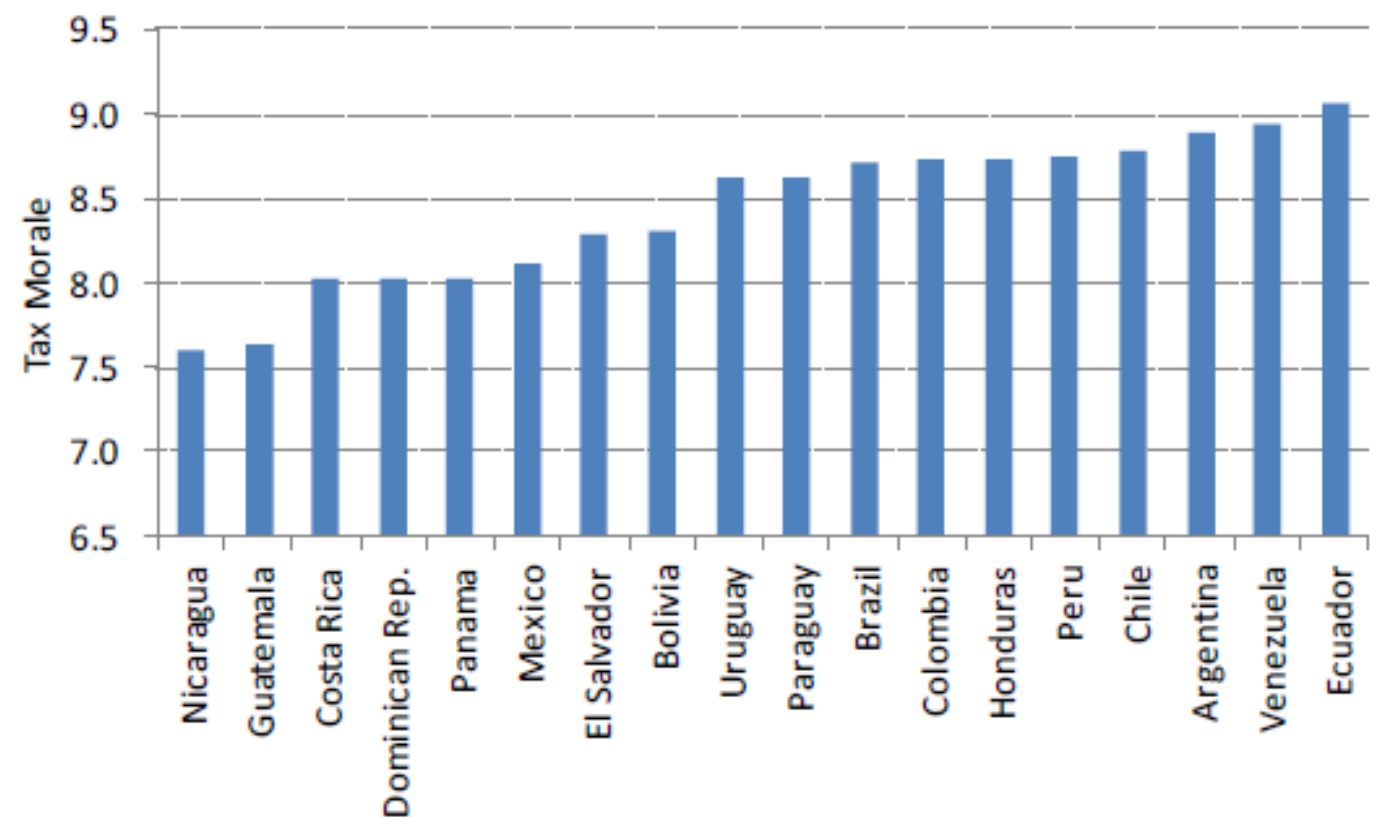

Fonte: Elaboração dos autores baseada no banco de dados do Latinobarómetro (2010).

Essa pesquisa, de certo modo, dá respaldo à desconfiança de Klaus Tipke (2012, p. 112) no sentido de que "o legislador, que não apresenta nenhuma moral impositiva inteligente, cujas leis tributárias como um todo estão muito longe de um código eticamente modelar, dificilmente pode construir nos contribuintes inibições moral-tributárias". Pelo contrário, "ele suprime sua consciência comunitária".

Setorialmente, a doutrina vem trabalhando há alguns anos com a ideia de moral tributária. Em teoria bastante difundida, Tipke e Yamashita (2002, p. 15) diferenciam ética de moral. Nessa concepção:

A Teoria da Justiça ou Ética é um ramo da Filosofia, também da Filosofia Política, assim como da Filosofia do Direito e do Estado. A Ética é a teoria dos princípios, regras, critérios ou padrões valorativos da justiça ou do comportamento justo. Ainda que na literatura os conceitos usados como sinônimos, nós entendemos como "Ética" a teoria do comportamento justo, e como "Moral" o comportamento ou agir segundo essa teoria.

Tipke liga a ética à teoria e a moral à prática. Realmente, ética e moral advêm de radicais distintos. Ética provém do grego ethos, que detém o sentido de caráter, modo de ser ou 
temperamento ${ }^{7}$. Moral se origina do latim mores, que é relativo a costumes, hábitos. Luhmann (1998, p. 201-202) conceituava moral como tipo específico de comunicação cujo âmbito é delimitado empiricamente, o qual comporta juízos ao apreço ou desapreço; a ética seria a descrição da moral e aspirada a ser uma teoria reflexiva da moral (Cf:: CABETTE, 2001, p. 31$41)^{8}$.

Na visão de Tipke (2012, p. 35), o legislador, que observa a teoria do Direito Tributário justo (respeitando direitos fundamentais), demonstra moral tributária ou age moralmente em matéria tributária. O cidadão, que paga impostos segundo leis tributárias justas, demonstra moral tributária ou age moralmente em matéria tributária (TIPKE; YAMASHITA, 2002, p. 15).

Não se têm notícias ainda de um estudo sociológico aprofundado sobre o fenômeno tributário na experiência brasileira ${ }^{9}$. Fernando Sáinz de Bujanda (1967, p. 22 e 149-150), que pesquisou as facetas pedagógicas da atividade financeira (conjugadas com aspectos econômicos e psicológicos), concordava com a arguciosa análise de Reynaud, concluindo que "a pressão fiscal psicológica é o resultado de uma larga elaboração na qual entra em jogo toda a personalidade". Embora concentrado na realidade espanhola, pode-se perfeitamente transportar as lições desse autor para as terras brasileiras, entendendo que à semelhança do que diz Ortega y Gasset (1908, p. 82) para a Espanha, o problema brasileiro também é educacional, dada a ausência de cidadania tributária no País; sendo necessário, portanto, numa lição profética, levar às escolas o desafio de aperfeiçoar o sentido do Direito e da Justiça na esfera da tributação.

É sabido que depois da Segunda Guerra houve aproximação do Direito com a moral: “a análise do aspecto material da lei é fundamental para a atual situação histórica que nos encontramos, isso porque, depois da segunda guerra mundial, tornou-se consenso de que nem

7 A palavra ethos iniciada com a letra epsylon significa caráter. Quando o termo começa pela letra grega etha, sendo escrito êthos, o significado será de morada, casa. O detalhamento etimológico dos dois radicais é muito mais complexo. $C f$ : COMPARATO, Fábio Konder. Ética: direito, moral, religião no mundo moderno. São Paulo: Companhia das Letras, 2008, 716 p. Martin Heidegger desenvolve o conceito de êthos (que significa morada) dizendo que o homem é a morada do ser. $C f$ : HEIDEGGER, Martin. Ser e tempo. Tradução de Márcia Sá Cavalcante Schulback. 15 . ed. Petrópolis: Vozes, 2005. 324 p.; HEIDEGGER, Martin. Introdução à metafísica. Tradução de Emmanuel Carneiro Leão. Rio de Janeiro: Tempo Brasileiro, 1969. 227 p.

$8 \quad$ De outro lado, Desidério Murcho sustenta a inutilidade da diferenciação conceitual entre ética e moral. $C f$ : MURCHO, Desidério. Ética e moral: uma distinção indistinta. Crítica, Revista de Filosofia e Ensino, v. 2004, p. 1, 2004.

Sobre a realidade francesa, $c f . .:$ ARDANT, Gabriel. Histoire de l'impôt. Paris: Fayard, 1971-1972. 
todo conteúdo legislativo poderia ser considerado direito" (ABBOUD; CARNIO; OLIVEIRA, 2013, p. 241) $)^{10}$.

Recorrendo à história da moral, Gilles Lipovestky (1994, p. 21-48) explica que no início a moral era Deus (a moral não era mais que uma parte do culto em que o homem deveria renderse a Deus). Na modernidade, a partir do século XVII, houve o resgate de pensamentos filosóficos gregos que consagravam a ideia de uma moral racional, elevando o indivíduo ao posto de valor moral primeiro e último: “o 'código genético' das democracias modernas é uma ética universalista e laica". No século XIX, época de grandes ideologias nacionalistas, o movimento moralista internacionalizou-se. A filantropia e as instituições de caridade ligadas à religião voltaram-se à materialização da lógica progressista e voluntarista moderna, professando-se a crença na força transformadora da educação humana e moral. Já na pós-modernidade, tudo mudou:

\begin{abstract}
A sociedade pós-moralista designa a época na qual o dever está amenizado e anêmico, em que a ideia de sacrifício de si está socialmente deslegitimada, em que a moral já não exige consagrar-se a um fim superior a um mesmo, em que os direitos subjetivos dominam os mandamentos imperativos, em que as lições de moral estão revestidas de spots do viver-melhor, como o sol das férias, a diversão midiática. Na sociedade do pósdever, o mal se espetaculariza e o ideal está pouco magnificado; se bem persiste a condenação dos vícios, o heroísmo do Bem é átono.
\end{abstract}

A igualdade, entendida como produto da justiça (ALEXY, 2010, p. 58-59) e como princípio que rege o cumprimento do dever de pagar tributos, também pode ser encaixada como direito fundamental. Tipke (2012, p. 35) assim conceituava a igualdade tributária. Aqui no Brasil, o STF já entendeu que princípios como os da anterioridade e irretroatividade, ligados à segurança jurídica, estariam abrangidos no rol das cláusulas pétreas como direitos fundamentais dos contribuintes ${ }^{11}$. Da mesma forma, o STF também já atribuiu esse caráter de norma inquebrantável à igualdade ${ }^{12}$.

10 ABBOUD, Georges; CARNIO, Henrique Garballini; OLIVEIRA, Rafael Tomaz de. Introdução à teoria e à filosofia do Direito. São Paulo: Revista dos Tribunais, 2013, p. 241.

$11 C f$ : : BRASIL, Supremo Tribunal Federal. ADI n. 939-7/DF, Pleno. Min. Relator: Sydney Sanches. In: DJ 18.03.1994.

$12 \quad C f:$ : BRASIL, Supremo Tribunal Federal. ADI n. 3.105/DF, Pleno. Min. Relatora Ellen Gracie, Rel. para acórdão Min. Cezar Peluso. Julgado em 18.02.2005. In: DJ de 18.02.2005; BRASIL, Supremo Tribunal Federal. ADI n. 3128/DF, Pleno. Min. Relator Ellen Gracie. Rel. para acórdão Cezar Peluso. In: DJ de 18.02.2005. 
Normalmente, têm-se deveres legais que se ligam ao exercício de direitos constitucionalmente previstos. Um exemplo claro é o direito à vida, que só é garantido na medida em que as outras pessoas respeitam o dever de não matar e/ou o de prestar socorro. Na contramão dessa lógica, o dever fundamental de pagar impostos dos contribuintes liga-se ao cumprimento de outros deveres pelo órgão competente (não confiscar, não cobrar sem lei etc.). Esses deveres do Estado, a seu turno, revestem-se do caráter de direitos ou garantias do contribuinte, como alude o caput do art. 150 da CF/88. Assim, é desacertado pensar que só o Estado possa esperar que o contribuinte aja com retidão (TIPKE, 2012, p. 111-112).

Tipke (2012, p. 112) afirma que a rapidez com que ocorrem as mudanças dos comandos legais impede a formação de uma consciência jurídica que se enraíze no senso comum e que torne as leis compreensíveis para a maioria dos cidadãos. A carência de continuidade (constancy of law through time) leva os contribuintes a crer que o conteúdo legal responde a caprichos legislativos e não a algum modelo ético.

Não é à toa que, nas ciências econômicas, os tributos são muitas vezes vistos apenas à luz de alguma estratégia de ganho e reduzidos à roupagem de elementos que afetam negativamente a lucratividade (Cf:: FAMA; FRENCH, 1998). É inegável a importância dos planejamentos para a atividade econômica; mas essa "frieza" serve para demonstrar que os tributos têm existido sem um profundo ancoramento na consciência da população (TIPKE, 2012, p. 112).

A política, embora indissociável dos atos legislativos (ABBOUD; CARNIO; OLIVEIRA, 2013, p. 241), também pode causar prejuízo moral ao utilizar o controle da exação para caçar eleitores por meio de privilégios fiscais. O favorecimento fiscal interesseiro, colocado nas leis pelos grupos político-partidários, desperta a fuga da tributação. Como ressalta Tipke (2012, p. 113), num contexto de concorrência entre os agentes econômicos, os contribuintes contratam assessores fiscais com know how para conseguir esquivar-se de pagar tributos ou diminuir o recolhimento aos cofres públicos. Nesse esteio, Gilles Lipovestky (1994, p. 128-132), falando da prevalência do self interest na atualidade, expõe que as sociedades pós-modernas renunciaram amplamente a professar o imperativo incondicional de honrar os deveres da moral interindividual: "mais direitos para nós, nenhuma obrigação de dedicar-se aos demais, tal é em termos abruptos, a fórmula do individualismo cabal". 
As recorrentes notícias de atos de corrupção com impunidade e a propagação de "opiniões" que atribuem ao Estado o vetusto papel de parasita dos contribuintes exercem efeitos nefastos sobre a moral tributária. Por consequência, "a aceitação das cargas tributárias tende a ser nula" (TIPKE, 2012, p. 114).

A transformação notada no campo moral influencia a política e repercute no Direito. Os subsistemas sociais sofrem incremento de complexidade por influência do ambiente (NEVES; SAMIOS, 1997, 111 p.), que lhes provocam irritações (CAMPILONGO, 2011, p. 95) ${ }^{13}$; e, para lidar com dinâmicas sociais distintas, eles se especializam (TEUBNER, 1989, p. 162). No Estado Democrático de Direito, desenvolve-se o fenômeno da setorização da atividade estatal na seara de captação e aplicação de recursos. Diante da percepção de que nem sempre os recursos públicos fossem corretamente geridos ou chegassem às pessoas necessitadas:

[...] o princípio do custo-benefício ganha uma dimensão coletiva e democrática, baseada na solidariedade de grupo, determinando que as despesas relacionadas a um segmento específico de contribuintes seja financiada pelos seus próprios integrantes, e não suportada pela sociedade em geral por meio de impostos (RIBEIRO, 2010, p. 1-25).

Com o resgate o princípio da equivalência neste contexto de ascensão da solidariedade de grupo, tende-se à superação do modelo apoiado exclusivamente em impostos, passando-se a preocupar com, além das causas da tributação (fato gerador), a finalidade dos tributos (RIBEIRO, 2010, p. 1-25).

\subsection{A capacidade contributiva como conteúdo do princípio da igualdade}

Na contemporaneidade, prevalece o entendimento de que a acepção da palavra "justiça" comporta mais de uma significação. "A justiça é considerada por muitos a principal virtude, a fonte de todas as outras". Em outra visão, a justiça contrabalança todos os outros valores (fiat justitia, pereat mundus: "faça-se justiça, ainda que o mundo pereça”). Percebe-se também certa

13 Marcelo Neves nega que o sistema jurídico nacional seja autopoiético. Para ele, é alopoiético, acreditando na força meramente simbólica da Constituição e negando a aplicabilidade (universalidade) da teoria de Luhmann para os Países do Terceiro Mundo (NEVES, Marcelo. From Autopoeisis to Allopioesis of Law. Journal of Law and Society, Oxford, Blackwell Pub., v. 28, n. 2, p. 242-264, 2001). 
subjetividade em relação ao que é justo; nas disputas, "cada qual defenderá uma concepção de justiça que lhe dá razão e deixa o adversário em má posição” (PERELMAN, 2005, p. 7-8).

Dentre os possíveis sentidos mais correntes da noção de justiça, Chaïm Perelman (2005, p. 7-8) enumera seis: 1) a cada qual a mesma coisa; 2) a cada qual segundo seus méritos; 3) a cada qual segundo suas obras; 4) a cada qual segundo suas necessidades; 5) a cada qual segundo sua posição; 6) a cada qual segundo o que a lei lhe atribui.

Os sentidos da justiça acima, em certos casos, são inconciliáveis ${ }^{14}$, mas "a noção de justiça sugere a todos, inevitavelmente, a noção de certa igualdade" (PERELMAN, 2005. P. 7 $8)^{15}$, sendo quase intuitivo afirmar que sem igualdade, não há justiça (VELLOSO, 2010, p. 8182). Então, se o que une todas essas acepções listadas por Perelman é a igualdade, existe uma variável que as diferencia umas das outras. Tais divergências estão na categorização (seleção) dos sujeitos aos quais se aplica a justiça.

No campo tributário, assentadas na aceitação geral da noção de proporcionalidade, foram desenvolvidas as teorias do sacrifício, com destaque para as do sacrifício igual e do sacrifício proporcional. Essas teorias passam a aplicar a ideia de igualdade ao dever de pagar os tributos, influenciando a formulação dos sistemas tributários ocidentais e representando a juridicização dos conceitos éticos justificadores da tributação. A partir dessas concepções que surgiram os consagrados princípios tributários da igualdade, generalidade, capacidade contributiva e proporcionalidade (MARINS, 1998, p. 25-26), todos eles aspectos parciais da justiça (SAINZ DE BUJANDA, 1993, p. 103-104).

De acordo com o princípio do sacrifício igual, um esquema tributário justo discrimina os contribuintes com base na renda, tirando mais de quem tem mais, para assegurar que cada pessoa sustente a mesma perda de bem-estar e garantir que a perda real, em oposição ao custo monetário para cada um, seja a mesma. A capacidade dos mais ricos de pagarem mais se justifica porque, mesmo se eles suportassem um sacrifício maior, ainda lhes restará mais renda: eles terão, em algum sentido, o suficiente - e estarão melhores que quem tinha menos originariamente.

14 Por exemplo, se se considerar que a noção de justiça encerra em atribuir a cada qual a mesma coisa, seria injusto o tratamento diferenciado conforme a posição, por este revestir-se de caráter aristocrático.

15 PERELMAN, Chaïm. Ética e Direito. Tradução de Maria Ermantina de Almeida Galvão. 2. ed. São Paulo: Martins Fontes, 2005, p. 7-8. 
Contudo, nem sempre se faz necessária a progressividade, pois esta dependerá do ritmo pelo qual a margem de utilidade dos rendimentos diminui (MURPHY; NAGEL, 2002, p. 24).

Victor Uckmar (1999, 145 p.), em exame comparativo na sua obra "Princípios comuns do direito constitucional tributário", observa que nos últimos séculos consolidaram-se os seguintes fundamentos constitucionais:

1) os impostos podem aplicar-se somente com base em uma lei que, em muitos Estados, deve ser promulgada segundo um procedimento particular e ser renovada anualmente (princípio da legalidade);

2) todos os contribuintes devem ser colocados, frente à carga fiscal, em um plano de igualdade (princípio da igualdade) de acordo com:

a) a generalidade e a uniformidade da tributação;

b) a abolição de qualquer privilégio ou discriminação (igualdade jurídica);

c) a aplicação dos impostos com base na capacidade econômica dos contribuintes, com

a tendência de introduzir no sistema fiscal impostos pessoais com alíquotas progressivas;

3) nos Estados em que as entidades locais gozam de autonomia financeira, cada entidade dotada de poder tributário deve exercitá-lo segundo os limites traçados na Constituição, sem obstaculizar o livre comércio no nível interno e com o exterior (princípio da competência) (Cf:: UCKMAR, 2002, p. 16-17).

Todos esses fundamentos listados pelo professor de Gênova estão na Constituição brasileira. Victor Uckmar (2002, p. 17) atribui como causa a essa concomitância histórica a “transmigração do Direito".

Conforme visto no tópico anterior, a definição da igualdade e a sua proximidade com o ideal de justiça são questões bastante discutidas na literatura jurídica. A fórmula proposta por Aristóteles e comentada por Rui Barbosa (1997, p. 26) - "Oração aos moços”: "tratar os iguais de forma igual e os desiguais de forma desigual na medida de sua desigualdade" esboça o espírito do princípio da igualdade material. Contudo, o problema é saber quem são os iguais e os desiguais ${ }^{16}$. Bobbio (1996, 48 p.), para quem a liberdade seria um estado e a igualdade uma relação, revela que essa tarefa de diferenciar é dificílima, na medida em que depende de ideias morais, políticas e sociais da doutrina que elabora a premissa: "igualdade entre quem? igualdade em quê?".

16 Luño assume o caráter relacional da igualdade e diz que essa relação se explicita na comparação entre os entes dos que se predica, um tertium comparationis (LUÑO, Antônio Enrique Perez. Dimensiones de la igualdad. 2. ed. Madrid: Dykinson, 2007, p. 18). 
Embora realmente exista tal questionamento sob o enfoque zetético, a Constituição atual brasileira já reduz bastante essa dificuldade (complexidade) ao impor cláusulas de diferenciação e de não-discriminação. A título de exemplo, a Constituição impõe a igualdade de tratamento entre os Estados (art. $4^{\circ}, \mathrm{V}$ ); entre homens e mulheres (art. $5^{\circ}, \mathrm{I}$ ); entre o empregado e o

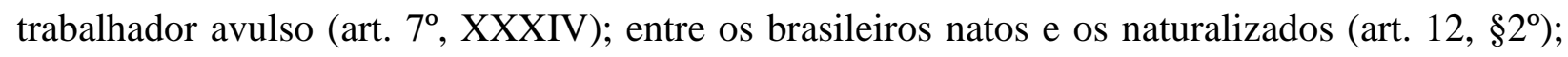
entre populações urbanas e rurais (art. 194, parágrafo único, II).

Ingo Sarlet descreve mudança no entendimento acerca do princípio da igualdade carreada pela Constituição de 1988:

(a) a igualdade compreendida como igualdade de todos perante a lei, onde a igualdade também implica a afirmação da prevalência da lei; (b) a igualdade compreendida como proibição de discriminação de qualquer natureza; (c) igualdade como igualdade da própria lei, portanto, uma igualdade "na" lei (SARLET; MARINONI; MITIDIERO, 2012, p. 526).

O princípio da igualdade material, embora não previsto expressamente no título relativo aos direitos e garantias fundamentais, está delineado no art. 150, II, proibindo-se aos entes tributantes instituir tratamento desigual entre contribuintes que se encontrem em situação equivalente, ou seja, permite-se a desigualação em virtude de algumas diferenças fáticas.

Sublinha-se a utilidade, para aferir eventuais ferimentos à isonomia tributária, da fórmula interpretativa do Tribunal Constitucional Federal alemão, segundo a qual esse princípio é violado quando se dispensa tratamento a um grupo de destinatários normativos de maneira distinta da de outros destinatários sem que exista diferenças de tal índole e de tal peso que possam justificar o tratamento desigual (VELLOSO, 2010, p. 59-60).

Esse patamar (ou situação equivalente a que alude o art. 150, II, CF/88) no qual os sujeitos se encaixam é revelado pela capacidade contributiva, que, pelo texto constitucional, determina graduação dos impostos segundo a capacidade econômica, sendo facultado, para dimensionar a aptidão para recolher tributos, à administração tributária identificar o patrimônio, os rendimentos e as atividades econômicas dos contribuintes. A graduação tendo por base a capacidade econômica é visualizada para a adequação da tributação no caso das cooperativas (art. 146, III, "c") e no favorecimento das empresas de pequeno porte e microempresas (art. 146, III, “d”), nos termos da lei complementar. No campo das contribuições sociais, o constituinte 
autoriza o legislador a estabelecer alíquotas ou bases de cálculo diferenciadas, adotando como critérios a atividade econômica, a utilização intensiva de mão-de-obra, o porte da empresa ou a condição estrutural do mercado de trabalho (art. 195, $\S 9^{\circ}$ ).

No que tange à progressividade para fins fiscais, o texto constitucional o declara ao IR (art. $\left.153, \S 2^{\circ}, \mathrm{I}\right)$, ao IPTU (art. $156, \S 1^{\circ}$ ) e ao ITR (art. 153, $\$ 4^{\circ}$, I). Já em relação ao ICMS e ao IPI, impostos incidentes sobre o consumo, prevê-se a seletividade das alíquotas tendo por base a essencialidade dos produtos (arts. $153, \S 3^{\circ}$, I e $155, \S 3^{\circ}$, III).

\section{DISTRIBUIÇÃO DA CARGA FISCAL NO BRASIL E EFEITOS SOCIOECONÔMICOS}

Especialistas tendem a destacar duas características quando descrevem o sistema tributário brasileiro: (1) a carga tributária é pesada em comparação com a de outras economias emergentes; e (2) o sistema contém distorções que comprometem os seus propósitos distributivos ( $C f:$ : LAVINAS; MOELLMANN FERRO, 2014, p. 1-35). De fato, entre a década de 1940 e 2013, o peso dos tributos sobre o PIB saltou de 14\% para 35,95\%. Embora esse patamar esteja próximo da média dos países da OCDE (35\%), o Brasil destes se diferencia pelo fato de a tributação indireta representar bem mais $(51,28 \%)$ do que o da mediana da OCDE (34\%).

Figura 2: Carga tributária brasileira por base de incidência.

\begin{tabular}{|c|c|c|c|c|c|c|c|c|c|c|}
\hline \multirow{2}{*}{ Cód. } & \multirow{2}{*}{ Tipo de Base } & \multicolumn{3}{|c|}{ RS milhões } & \multicolumn{3}{|c|}{$\%$ PIB } & \multicolumn{3}{|c|}{ \% da Arrecadação } \\
\hline & & 2012 & 2013 & Variação & 2012 & 2013 & $\begin{array}{l}\text { Var (p.p. } \\
\text { do PIB) }\end{array}$ & 2012 & 2013 & $\begin{array}{c}\text { Var (p.p. } \\
\text { da Arrec.) }\end{array}$ \\
\hline 0000 & Total: & $1.574 .860,82$ & $1.741 .658,31$ & $166.797,49$ & $35,86 \%$ & $35,95 \%$ & 0,09 & $100,00 \%$ & $100,00 \%$ & 0,00 \\
\hline 1000 & Renda & $281.645,66$ & $315.276,04$ & $33.630,38$ & $6,41 \%$ & $6,51 \%$ & 0,09 & $17,88 \%$ & $18,10 \%$ & 0.22 \\
\hline 2000 & Folha de Salários & $404.484,90$ & $435.062,92$ & $30.578,01$ & $9,21 \%$ & $8,98 \%$ & $-0,23$ & $25,68 \%$ & $24,98 \%$ & $-0,70$ \\
\hline 3000 & Propriedade & $61.090,83$ & $68.408,47$ & $7.317,64$ & $1,39 \%$ & $1,41 \%$ & 0,02 & $3,88 \%$ & $3,93 \%$ & 0.05 \\
\hline 4000 & Bens e Serviços & $797.003,75$ & $893.055,30$ & $96.051,55$ & $18,15 \%$ & $18,43 \%$ & 0,29 & $50,61 \%$ & $51,28 \%$ & 0.67 \\
\hline 5000 & Transações Financeiras & $30.746,81$ & $29.162,89$ & $-1.583,92$ & $0,70 \%$ & $0,60 \%$ & $-0,10$ & $1,95 \%$ & $1,67 \%$ & $-0,28$ \\
\hline 9000 & Outros & $-111,13$ & 692,69 & 803,82 & $0,00 \%$ & $0,01 \%$ & 0,02 & $-0,01 \%$ & $0,04 \%$ & 0,05 \\
\hline
\end{tabular}

Fonte: Ministério da Fazenda, Receita Federal, CETAD - Centro de Estudos Tributários e Aduaneiros (2014). 
Relatório do Conselho de Desenvolvimento Econômico e Social - CDES, lista cinco problemas do sistema tributário brasileiro do ponto de vista da justiça social, acompanhados de seus respectivos indicadores e dados ${ }^{17}$ :

a) O sistema tributário é regressivo com carga fiscal mal distribuída. Considerando a carga tributária por faixa de salário mínimo, a POF 2002/2003 indicou que as pessoas que auferem até dois salários por mês pagam $48,8 \%$ de renda em tributos; enquanto que as de renda superior a 30 salários mínimos sofreram a carga de 26,3\%. Na POF 2008/2009, esse quadro pouco se alterou ${ }^{18}$;

b) o retorno social é baixo em relação ao peso fiscal. Menos de um terço $(10,4 \%$ de um total de 34,9\%) da carga tributária arrecadada é direcionada para investimentos sociais (saúde, educação, segurança pública, habitação e saneamento).

c) a estrutura tributária desincentiva as atividades produtivas e a geração de emprego. A cumulatividade, a grande quantidade de tributos e a incidência sobre a folha de pagamentos foram eleitas como as principais causas ligadas à tributação que travam a economia;

d) inadequação do pacto federativo em relação às suas competências tributárias, responsabilidades e territorialidades. Prejudicando o cumprimento do objetivo constitucional de redução das desigualdades regionais, verifica-se discrepância entre os orçamentos dos entes federados categorizados como mais ricos e mais pobres - em 2009, o orçamento médio per capita dos dez municípios mais ricos ( $\mathrm{R} \$ 9.478$ ) superou em dezoito vezes o orçamento médio por habitante dos dez mais pobres ( $\mathrm{R} \$ 512)$. Em média, os dez mais ricos receberam $(\mathrm{R} \$ 7.497) 20$

$17 \quad C f:$ : CONSELHO DE DESENVOLVIMENTO ECONÔMICO E SOCIAL. Indicadores de Iniquidade do Sistema Tributário Nacional: Relatório de Observação n. 2. 2. ed. Brasília: Presidência da República, Conselho de Desenvolvimento Ecônômico e Social - CDES, 2011. 60 p.

$18 \quad C f:$ INSTITUTO BRASILEIRO DE GEOGRAFIA ESTATÍSTICA. Pesquisa de Orçamentos Familiares 2008/2009. Despesas, Rendimentos e Condições de vida. Rio de Janeiro: IBGE, 2010, 222 p. 
vezes mais transferências intergovernamentais do que os dez municípios mais pobres $(\mathrm{R} \$ 373)$;

e) não há cidadania tributária. Falta transparência e harmonização na cobrança das contribuições sociais, além de existir imensa fragmentação nas legislações dos entes federados subnacionais ${ }^{19}$.

Nesse mesmo sentido, Eros Roberto Grau (2015, p. 45) assevera que "a carga tributária não é relativamente tão elevada, como se tem afirmado (geralmente por ignorância, mas também por má-fé, em alguns casos), mas acentuadamente regressiva. O trabalho é muito mais vigorosamente tributado do que o capital".

Klaus Tipke aduzia que a renda seria a única fonte de impostos e, sob o prisma da capacidade contributiva, haveria três "bens tributáveis": a renda (auferida), o patrimônio (renda acumulada) e o consumo (renda despendida) (TIPKE; YAMASHITA, 2002, p. 109-110). Com base nessa tripartição e sem listar por enquanto os fatores que conduziram a essa configuração, percebe-se que a política tributária brasileira centra sua incidência no consumo e sacrifica menos o patrimônio e a renda.

19 “Cidadania tributária significa a conscientização do cidadão para o fato de que a necessária arrecadação de tributos deve reverter-se em benefícios que cumpram o papel de atender às necessidades da coletividade, reduzindo distâncias sociais. Transparência, tanto no que diz respeito às fontes quanto aos usos dos recursos públicos é palavra-chave e primeiro requisito para o exercício da cidadania tributária". Cf.: CONSELHO DE DESENVOLVIMENTO ECONÔMICO E SOCIAL. Indicadores de Iniquidade do Sistema Tributário Nacional: Relatório de Observação n. 2. 2. ed. Brasília: Presidência da República, Conselho de Desenvolvimento Ecônômico e Social-CDES, 2011. 60 p. 


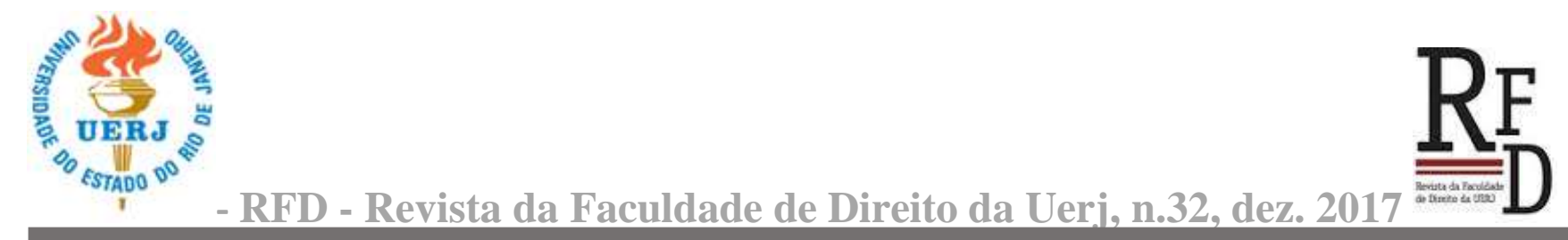

Figura 3: Carga Tributária por base de incidência - Brasil e paises da OCDE (2012).

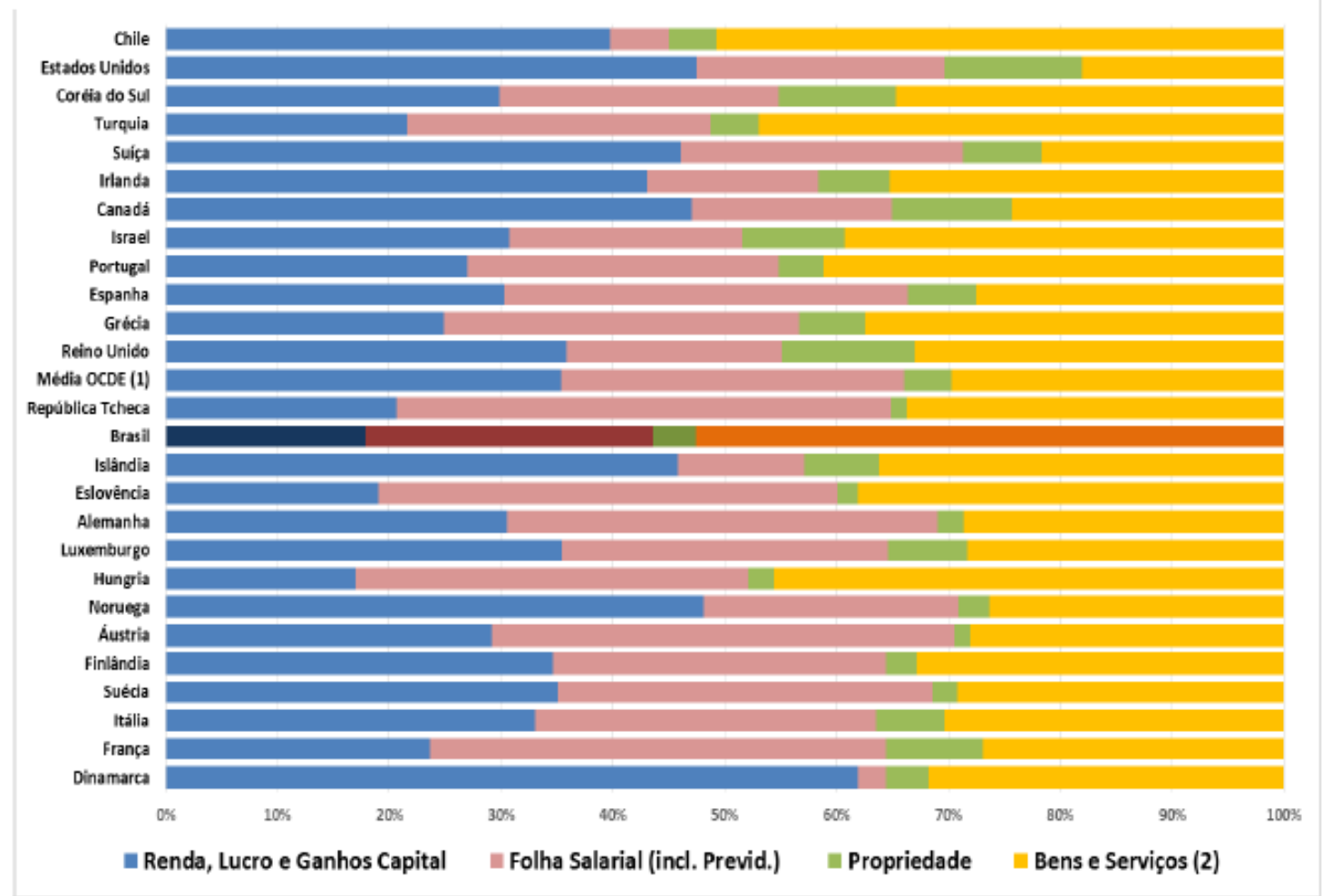

Fonte: Ministério da Fazenda, Receita Federal, CETAD - Centro de Estudos Tributários e Aduaneiros (2014).

A oneração maior do consumo é causa comprovada da regressividade; não tendo sido a

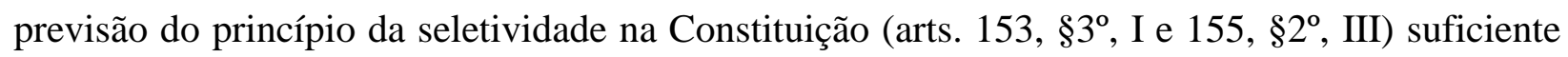
para reverter ou atenuar a tendência regressiva da tributação indireta. Com base na POF 2002/2003, Maria Helena Zockun (2007, 101 p.) traçou o panorama de que a tributação indireta onera em $45,8 \%$ a renda de quem recebe até dois salários mínimos mensais; ao passo que as pessoas de renda superior a trinta salários mínimos sofreram a carga de 16,4\%. A tributação direta, que é menos praticada e mais progressiva ( $C f:$ ROCHA, 2002, p. 73-105), afetou 3,1\% da renda daqueles na faixa de renda de até dois salários mínimos e 9,9\% dos que auferiram mais de trinta salários mínimos.

O federalismo, forma de Estado caracterizado pela descentralização, constitui ordem política e constitucional com certas especificidades. O sistema federal brasileiro, introduzido em 1889 e detalhado na Constituição de 1891, à semelhança do americano e diferentemente do modelo adotado na Europa continental, está assentado no individualismo lockeano, que tem por 
concepção que os direitos fundamentais têm a sua origem nos indivíduos, e não no Estado ( $C f$ : LOCKE, 2001, 639 p.).

Estabeleceu-se o consenso de que o principal problema do federalismo brasileiro são as heterogeneidades econômicas entre as regiões. Critica-se a Constituição de 1988 em razão de os mecanismos constitucionais para a diminuição dos desequilíbrios regionais não terem sido operacionalizados ou serem insuficientes para uma efetiva política de equalização fiscal (SOUZA, 2005, p. 105-121). Por isso, a quantificação da arrecadação tributária em razão do ente político pertine ao tema da justiça fiscal.

No regime militar, embora tenha ocorrido a centralização política na esfera federal; nesse mesmo interregno, foram concebidos mecanismos de transferência de recursos para os entes subnacionais (Fundo de Participação dos Estados - FPE, e Fundo de Participação dos Municípios - FPM) (Cf:: REZENDE, 1996, 18 p.). E apesar do intuito descentralizador do constituinte de 1988, que instituiu e ampliou fórmulas de repartição de receitas tributárias (art. 157 a 159), e da competência/incumbência comum de todos os entes para prover serviços essenciais como educação, saúde e saneamento básico; como se pode ver no quadro abaixo, a União continua concentrando fortemente o montante captado.

Figura 4: Receitas tributárias por entes federativos.

\begin{tabular}{|c|c|c|c|c|c|c|c|c|c|}
\hline \multirow{2}{*}{ Entidade Federativa } & \multicolumn{3}{|c|}{2012} & \multicolumn{3}{|c|}{2013} & \multicolumn{3}{|c|}{ Variação } \\
\hline & RS milhões & $\%$ do PIB & $\begin{array}{c}\% \text { da } \\
\text { Arrecad. }\end{array}$ & RS milhões & $\%$ do PIB & $\begin{array}{c}\% \text { da } \\
\text { Arrecad. }\end{array}$ & RS milhões & $\begin{array}{l}\text { p.p. do } \\
\text { PIB }\end{array}$ & $\begin{array}{c}\text { p.p.da } \\
\text { Arrecad. }\end{array}$ \\
\hline União & $1.087 .632,34$ & $24,76 \%$ & $69,06 \%$ & $1.200 .337,25$ & $24,78 \%$ & $68,92 \%$ & $112.704,91$ & 0,01 & $-0,14$ \\
\hline Estados & $396.338,82$ & $9,02 \%$ & $25,17 \%$ & $440.400,79$ & $9,09 \%$ & $25,29 \%$ & $44.061,97$ & 0,07 & 0,12 \\
\hline Municípios & $90.889,66$ & $2,07 \%$ & $5,77 \%$ & $100.920,27$ & $2,08 \%$ & $5,79 \%$ & $10.030,61$ & 0,01 & 0,02 \\
\hline Receita Tributária Total: & $1.574 .860,82$ & $2 \quad 35,86 \%$ & $100,00 \%$ & $1.741 .658,31$ & $35,95 \%$ & $100,00 \%$ & $166.797,49$ & 0,09 & 0,00 \\
\hline
\end{tabular}

Fonte: Ministério da Fazenda, Receita Federal, CETAD - Centro de Estudos Tributários e Aduaneiros (2014).

Para Mário Eduardo Martinelli (2009, p. 246), a Constituição de 1988 impõe ao Estado brasileiro o compromisso da superação do homem supérfluo. Contudo, os objetivos prescritos no art. $3^{\circ}$ da $\mathrm{CF} / 88$ e os princípios tributários ligados à justiça, precisam necessariamente passar pela etapa da interiorização, precedida de uma ampla reflexão crítica, estágio este imprescindível para integrar a consciência geral. 
Concorda-se com o Professor José Renato Nalini quanto à necessidade de que "o Direito Tributário, num país de desigualdades e de iníqua repartição de rendas, não pode se afastar de sua inspiração ética”. O Professor Nalini (2009, p. 121-143), ao diferenciar Direito e moral, afirma que "o ato moral postula discernimento, para assim ser considerado. $\mathrm{O}$ ato jurídico pode ser praticado inconscientemente e não perderá esse atributo". Na visão deste trabalho, esta distinção aplica-se em relação às regras, principalmente àquelas que padecem de pouca ou nenhuma ambiguidade e/ou vagueza. Os princípios, por muitas vezes praticarem a heterorreferência em direção ao campo axiológico, podem também requisitar reflexão aprofundada para sua compreensão e aplicação no subsistema jurídico.

A consciência (capacidade para integrar, categorizar e acessar informação através de um sistema cognitivo - Cf:: TEIXEIRA, 1997, p. 109-128) da sociedade constitui elemento genético do fenômeno da tributação cujo patamar ético está espelhado nas leis: “Ética e Direito são 'faces da mesma moeda', portadoras das mesmas potencialidades e limites" (CABETTE, 2001, p. 3141).

Saínz de Bujanda (1967, p. 18-19) constatou que todas as teorias que se propunham a explicar o fenômeno tributário a partir de uma abordagem exclusivamente econômica (ou seja, primariamente cognitiva) falharam por desconhecer os pressupostos sociopolíticos da fazenda pública, assim como o complexo anímico dos contribuintes, aspecto este irredutível a um puro critério de economicidade.

Nesse viés, examinar o funcionamento e realçar as especificidades do sistema político ajuda bastante a entender o sistema tributário vigente, já que ele, em última instância, é configuração que espelha as correlações de forças existentes.

\subsection{Tributação e quotidiano político}

Como ressalta Victor Uckmar (2002, p. 16), o embrião da democracia moderna encontra raízes nas lutas por igualdade de participação no veio político para a instituição de tributos. Na Magna Carta, expressava-se que "não há tributação sem representação" ("no taxation without representation"); a revolução americana inicia-se com a revolta contra a aplicação dos "direitos 
aduaneiros" pretendidos pela Coroa; e a revolução francesa tem como base a aversão aos privilégios fiscais do clero e da nobreza. $\mathrm{Na}$ atualidade, existem as associações de contribuintes que defendem tributos justos (TIPKE, 2012, p. 110-111).

O jogo político na América Latina envolve diversos atores como partidos políticos, elites econômicas, militares, camponeses, governos estrangeiros, sindicatos e muitos outros. Esses grupos costumam exercer influência mais sobre a maneira em que o processo político se desenvolve do que propriamente sobre os resultados. Gary Wynia (1978, p. 44-52, ao estudar a política latinoamericana, observou que a elite econômica, frequentemente culpada pelo subdesenvolvimento da região, não é monolítica em sua atuação social. O autor observou, por exemplo, diferenças entre os grandes proprietários rurais. Enquanto os latifundiários monocultores sustentaram posição mais defensiva no espectro político, para apenas barrar o tolhimento de suas riquezas; os agroindustriários são organizados e querem mais do governo. Estes participam da formulação das políticas agrárias e de logísticas, constituem lobbies, financiam e elegem parlamentares, acompanham de perto as relações internacionais.

A elite urbana (dos ramos industrial, financeiro e comercial) age de forma diferente da rural. Eles procuram crédito fácil, principalmente se se sentirem ameaçados por empresas estrangeiras maiores e mais eficientes. Opõem-se aos sindicatos de trabalhadores, compartilham antipatia em relação à tributação e tratam dos seus interesses diretamente (mas não abertamente com a supervisão do público) com a classe política. "Quando ameaçados por tributos mais altos e regulações indesejáveis, eles avisam ao governo a calamidade econômica que resultará" (WYNIA, 1978, p. 52-54).

A estabilidade dos governos dependem da cooperação de múltiplos atores políticos, sendo um dos trabalhos mais difíceis na América Latina implementar reformas sem romper com a democracia. Ao contrário dos conservadores, que podem agarrar-se ao status quo vigente, ou dos revolucionários, que eliminam fisicamente seus inimigos, o reformador democrático deve operar dentro da ordem tradicional enquanto tenta mudá-la. E, para tanto, a única esperança é, usando timing preciso, apostar numa coalizão poderosa com sustentáculos nos campos social, econômico e político (WYNIA, p. 205-207). Na história brasileira, o ímpeto reformista falhou claramente em 1964. 
Shapiro e Graetz (2005, p. 4-11) expõem a dinâmica oculta da legiferação ao narrar um episódio em que a maioria do Congresso americano votou pela derrubada do imposto sobre heranças. A pergunta feita por eles é intrigante: Como que pessoas não contribuintes do imposto sobre heranças, e que em última instância teriam seus próprios tributos elevados para compensar as perdas de receitas se esse tributo desaparecesse, vieram a se opor a ele? Quem fez isso ocorrer? As respostas vêm de como a política tem sido praticada hoje em dia numa era de enquetes, chavões, think-tanks, associações organizadas e lobby escorado no financiamento de campanhas eleitoras e legendas partidárias. Em menos de uma década, a ideia disseminada de riqueza foi transmudada de privilégio social para direito natural com o reforço de vários argumentos (como o da dupla tributação - a renda sofreria tributação quando é auferida e quando é transmitida aos sucessores) e exemplos (como o de Bill Gates, que começou seu negócio numa garagem e tornou-se bilionário).

A opção do legislador pela captação da maior parte dos recursos através da tributação indireta, embora muito criticável, tem explicações racionais. Como ensina Nabais (2007, p. 124), o recolhimento de impostos foi suavizado com o tempo, de modo a anestesiar a sensação de perda sentida pelo homem ao pagar impostos. Em analogia à bíblia, segundo a qual Deus criou Eva retirando uma costela de Adão enquanto este dormia, o padre Antonio Vieira propôs em 1642, às Cortes portuguesas, a imposição de tributos mais suave (embutida) porque menos perceptível. Vito Tanzi (2013, p. 2-4) observa que a focalização nos tributos indiretos na América Latina fez com que esses países aprimorassem a fiscalização e o recolhimento desses tributos (como, por exemplo, através da praticabilidade), o que produziu significativa eficiência na arrecadação e redução de evasões fiscais. A sonegação de tributos diretos passou a ter como "soldado de reserva" 20 os tributos indiretos, a incidir sobre todo tipo de consumo.

A descrição feita por Shapiro e Graetz sobre o Congresso norte-americano guarda semelhança com a atual experiência brasileira. No período pós-1988, há exemplos de discursos disseminados no sistema político que parecem discrepar da visão do constituinte de que a justiça tributária seria instrumental para a justiça social (MURPHY; NAGEL, 2002, p. 174-176). A não-

20 "Soldado de reserva" é expressão do penalista Nelson Hungria, que trouxe o entendimento do princípio da subsidiariedade na esfera penal, de modo que a norma subsidiária (geral) mais branda seria aplicada caso houvesse impossibilidade de aplicação da norma penal especial mais grave ( $C f$ : HUNGRIA, Nelson. Comentários ao Código Penal. Vol. I, tomo I., Rio de Janeiro: Forense, 1958, p. 139). 
instituição, até hoje, do imposto sobre grandes fortunas (art. 153, VII, CF/88), tributo este destinado a incidir sobre a riqueza líquida acumulada, é um caso que ilustra a resistência da classe política à justiça distributiva. Os argumentos são sempre os mesmos: baixa arrecadação, alto custo administrativo e a sua extinção em diversos países europeus. Essas "razões" não são tão consistentes, havendo países em que esse imposto é bastante consagrado (França e Argentina) e com baixos custos administrativos. No caso da Holanda, esse tributo foi substituído por outro imposto sobre a propriedade, o Imposto de Ganho sobre o Capital Pessoal Presumido; na Suécia, foi extinto por já ter atingido seus propósitos redistributivos (CARVALHO JÚNIOR, 2011, 50 p.).

Nessa senda de exame do conjunto das leis com base no postulado da capacidade contributiva, vêem-se algumas inconsistências como a subtributação do lucro (através da isenção de IRPF sobre a distribuição de lucros e dividendos, e dos juros sobre capital próprio - arts. $9^{\circ}$ e 10 da Lei n. 92.49/1995); as alíquotas modestas do ITCMD praticadas nos Estados; e a nãoincidência do IPVA sobre a propriedade de aeronaves e embarcações. 
Figura 5: Aliquotas dos impostos sobre herança e doações pelo mundo.

\begin{tabular}{|c|c|c|c|c|}
\hline \multirow[t]{2}{*}{ País } & \multicolumn{2}{|c|}{$\begin{array}{c}\text { Imposto sobre } \\
\text { Herança }\end{array}$} & \multicolumn{2}{|c|}{$\begin{array}{l}\text { Imposto sobre } \\
\text { Doação }\end{array}$} \\
\hline & Médio & Máximo & Médio & Máximo \\
\hline BRASIL & $3,86 \%$ & $8,00 \%$ & $3,23 \%$ & $8,00 \%$ \\
\hline EUA & $29,00 \%$ & $40,00 \%$ & $29,00 \%$ & $40,00 \%$ \\
\hline Alemanha & $28,50 \%$ & $50,00 \%$ & $28,50 \%$ & $50,00 \%$ \\
\hline Austrália & $0,00 \%$ & $0,00 \%$ & $0,00 \%$ & $0,00 \%$ \\
\hline Canadá & $0,00 \%$ & $0,00 \%$ & $0,00 \%$ & $0,00 \%$ \\
\hline Chile & $13,00 \%$ & $25,00 \%$ & $18,20 \%$ & $35,00 \%$ \\
\hline China & $0,00 \%$ & $0,00 \%$ & $0,00 \%$ & $0,00 \%$ \\
\hline França & $32,50 \%$ & $60,00 \%$ & $25,00 \%$ & $45,00 \%$ \\
\hline Índia & $0,00 \%$ & $0,00 \%$ & $15,00 \%$ & $30,00 \%$ \\
\hline Inglaterra & $40,00 \%$ & $40,00 \%$ & $30,00 \%$ & $40,00 \%$ \\
\hline Itália & $6,00 \%$ & $8,00 \%$ & $6,00 \%$ & $8,00 \%$ \\
\hline Japão & $30,00 \%$ & $50,00 \%$ & $30,00 \%$ & $50,00 \%$ \\
\hline Luxemburgo & $24,00 \%$ & $48,00 \%$ & $8,10 \%$ & $14,40 \%$ \\
\hline México & $0,00 \%$ & $0,00 \%$ & $0,00 \%$ & $0,00 \%$ \\
\hline Noruega & $0,00 \%$ & $0,00 \%$ & $0,00 \%$ & $0,00 \%$ \\
\hline Russia & $0,00 \%$ & $0,00 \%$ & $0,00 \%$ & $0,00 \%$ \\
\hline Suécia & $0,00 \%$ & $0,00 \%$ & $0,00 \%$ & $0,00 \%$ \\
\hline Suiça & $25,00 \%$ & $50,00 \%$ & $25,00 \%$ & $50,00 \%$ \\
\hline
\end{tabular}

Fonte: Levantamento da consultoria EY - Ernst \& Young (2014).

Embora seja de utilidade inequívoca um estudo destinado a identificar as circunstâncias de ordem política que desencadeiam distorções no sistema tributário, tenta-se aqui evidenciar questões de natureza jurídica que acometem o princípio da igualdade de inefetividade. 
A Constituição é estrutura pertencente à política e ao Direito, passando mensagens para esses dois sistemas. Do lado político, um princípio pode ser inquestionavelmente e amplamente desenvolvido, dada a ampla capacidade cognitiva da política para criar e suprimir normas. No sistema jurídico, há limites mais duros, que são os mesmos que decorrem das possibilidades de operação com o seu código binário (LUHMANN, 2005, p. 74-76).

O Direito trabalha com normas, que, do ponto de vista sociológico, são expectativas contrafáticas; opera com um código binário próprio, de modo que o sistema se diferencie para cumprir a sua tarefa específica de resolver o problema da defraudação de expectativas e servir à reprodução autopoiética do sistema:

\begin{abstract}
O processamento de ditas expectativas precisa de um código binário que contenha um valor positivo (a justiça) e um valor negativo (a injustiça), assim como que exclua artificialmente ambas contradições - v.g. a justiça é injusta e a injustiça é justa - e outros valores (a utilidade, os fins políticos, etc). Esta codificação tem uma importância decisiva para a diferenciação do sistema jurídico, posto que dota o sistema de sua própria forma de contingência, a qual está internamente constituída. Tudo aquilo que entre dentro da esfera da relevância jurídica pode ser legal ou ilegal. Tudo aquilo que encaixe dentro desse código só terá relevância jurídica se resulta importante como questão preliminar às decisões sobre a justiça e à injustiça (LUHMANN, 2005, p. 74).
\end{abstract}

Os princípios apresentam, na cadeia argumentativa, uma maior capacidade de desenvolver a heterorreferência, pois, de certa maneira, apontam para algo que existe fora do sistema jurídico (valores, princípios morais, interesses gerais, etc.). Considerando a codificação binária do sistema jurídico, Marcelo Neves (2013, p. 120-132) alerta para o possível perigo do abuso de princípios, posto que como os princípios detém maior abrangência e mobilidade, eles podem servir "[...] retoricamente para encobrir manipulações que bloqueiam a autoconsciência constitucional da respectiva ordem jurídica".

\title{
3.1 Aplicação jurisdicional do princípio da capacidade contributiva
}

A expressão "sempre que possível" do art. 145, $\S 1^{\circ}$ da Constituição Federal de 1988 suscita dúvidas sobre a eficácia do princípio da capacidade contributiva. Na obra de Klaus Tipke e Douglas Yamashita (2002, p. 51-52), valendo-se das lições de Marco Aurélio Greco (2000, p. 187), estes autores explicam que existem três correntes interpretativas acerca dessa cláusula: "sempre que possível sem força", "sempre que possível fraco" e "sempre que possível forte". 
O "sempre que possível sem força" nega a normatividade do princípio, sendo entendido como princípio constitucional inútil. Tendo em vista tratar de princípio disposto na Constituição que se liga à ideia de justiça distributiva, tal concepção é inadmissível. O "sempre que possível fraco" é considerado insuficiente, pois restringe a aplicação da capacidade contributiva aos casos em que não haveria riqueza passível de tributação (proteção do mínimo existencial ${ }^{21}$ e fundamento da imunidade intergovernamental ${ }^{22}$ ). Já o "sempre que possível forte" envolveria, além de imunizar a indisponibilidade de recursos para recolher tributos, as situações em que a capacidade contributiva não é adequadamente captada (GRECO, 2000, p. 187).

Há diversas técnicas (ou subprincípios) que têm por escopo a adequação da carga tributária à capacidade contributiva, para além da mera proporcionalidade, de acordo com hipótese de incidência de cada tributo: (a) para os tributos sobre o consumo, impõe-se a seletividade; (b) para os tributos pessoais, funciona a pessoalidade, que propicia a progressividade; (c) para os tributos reais, rege a patrimonialidade, que admite a progressividade; (d) nos tributos vinculados, calcula-se o montante a ser pago pelo custo-benefício, sempre condicionado à manutenção do mínimo vital (que é imune). Analisar-se-á, com base nessa pequena estruturação, a força obrigacional dos princípios ligados à justiça reconhecida na jurisprudência.

\subsubsection{Princípio da seletividade}

Na tributação do consumo, o legislador elenca a incidência do princípio da seletividade (subprincípio da capacidade contributiva - Cf:: TORRES, 2009, p. 377) para o IPI e o ICMS, segundo o qual a variação de alíquotas deva se dar conforme a essencialidade das mercadorias transmitidas. Essa determinação constitucional tem como conteúdo que a estipulação das alíquotas será feita na razão inversa da necessidade da mercadoria para a população e em razão

21 Ao Estado não é permitido exercer exação sobre o mínimo existencial porque lhe é defeso retirar com uma mão (tributar) e dar com a outra (prover assistência social) (TIPKE, Klaus; YAMASHITA, Douglas. Justiça Fiscal e Princípio da capacidade contributiva. São Paulo: Malheiros, 2002, p. 34). Esse é o fundamento da imunidade das pequenas glebas rurais voltadas à subsistência do seu proprietário, de modo que o físco não cause o êxodo rural por meio da tributação e leve a população camponesa à miséria nos espaços urbanos.

$22 \quad C f$ : BRASIL, Supremo Tribunal Federal. Ag.Rg. no RE n. 482.814/SC, Segunda Turma. Min. Relator Ricardo Lewandowski. In: DJ de 14.12.2011. 
direta da sua superfluidade (TORRES, 1997, p. 94-102). Trata-se de medida de justiça (ou de atenuação de injustiça - Cf:: MELO, 2009, p. 211) para esses impostos, que são insensíveis às características pessoais dos contribuintes. Todavia, a partir da seletividade, não se pode deduzir imunidade, ainda que as operações ou os bens sejam essenciais ao ser humano, prevalecendo “[...] o postulado da solidariedade no custeio das atividades estatais" ${ }^{23}$.

A seletividade, enquanto norma jurídica, parece proibir, ao menos prima facie, a instituição de alíquotas elevadas a produtos de caráter essencial. Essenciais, sem fazer qualquer esforço interpretativo, seriam aqueles produtos inseparáveis da promoção da dignidade humana (art. $1^{\text {o }}, \mathrm{III}, \mathrm{CF} / 88$ ) e da proteção do mínimo existencial ${ }^{24}$.

Embora a Constituição já caminhe para completar seu trintenário, o Judiciário, apesar de provocado, ainda não firmou posições sólidas para solucionar determinadas situações controversas ( $C f .:$ ROCHA; FERNANDES, 2015, p. 107-125). O Superior Tribunal de Justiça apresenta algumas dezenas de acórdãos publicados em que se discutiu a aplicação do princípio da seletividade. Mesmo se tratando de questão constitucional, o que inviabilizou o julgamento aprofundado de muitos recursos, como, por exemplo, o do REsp n. 123.703/GO ${ }^{25}$, o STJ entende que não seria possível ao Poder Judiciário, se entendesse inconstitucional a alíquota, a fixação de uma nova, por lhe ser vedado atuar como legislador positivo ${ }^{26}$.

Tem-se a perspectiva de que o tema será debatido, em relação ao ICMS, mais uma vez, pois o STF, em junho de 2014, reconheceu repercussão geral do RE n. 714.139/SC, no qual se questiona a validade de norma estadual que prevê alíquota de $25 \%$ de ICMS incidente no fornecimento de energia elétrica e nos serviços de telecomunicação, em nível superior ao estabelecido para as operações em geral - 17\%. No parecer da PGR, essa discrepância deve ser julgada inconstitucional, a par das alegações de violação da separação dos poderes; fazendo-se

23 BRASIL, Supremo Tribunal Federal. RE n. 429.306/PR, Segunda Turma. Min. Relator Joaquim Barbosa. In: DJe n. 49, de 15.03.2011.

24 BRASIL, Supremo Tribunal Federal. AgRg no RE n. 634.457/RJ, Segunda Turma. Min. Relator Ricardo Lewandowski. In: DJe de 15.08.2014.

25 BRASIL, Superior Tribunal de Justiça. REsp n. 123.703/GO, Primeira Seção, Primeira Turma. Min. Relator Demócrito Reinaldo. In: DJ de 22.06.1998.

26 BRASIL, Superior Tribunal de Justiça. REsp n. 20.676/ES, Primeira Seção, Primeira Turma. Min. Relatora Denise Arruda. In: DJ de 20.09.2007. 
incidir nas operações relativas a energia elétrica, por consequência e até a superveniência de produção legislativa, a alíquota prevista para as operações em geral.

Quanto ao IPI, está previsto julgamento (RE n. 606.314/PE) em que se discute a possibilidade de o Judiciário estabelecer alíquota inferior àquela correspondente à classificação do produto que a autoridade fiscal entende como correta. Neste último caso, já foi protocolizado o parecer da Procuradoria Geral da República relembrando a vasta jurisprudência do tribunal que entende ser inconcebível ao Judiciário atuar como legislador positivo. Na visão da PGR, caso houvesse violação do princípio da seletividade, dever-se-ia extirpar do ordenamento a norma contestada em juízo, o que acarretará desoneração tributária do produto por faltar-lhe aspecto quantitativo.

Conclui-se, então, que a dificultada aplicabilidade judicial praticada pelos tribunais superiores do princípio constitucional da seletividade contribui para que ele, reiteradamente, não seja levado em conta na estipulação das alíquotas.

\subsubsection{Princípios da pessoalidade e da patrimonialidade}

No Estado Social, a capacidade contributiva passou a ser fundamentada na justiça distributiva, através da solidariedade social, a informar o princípio da personificação (RIBEIRO, 2010, p. 1-25). O art. 134 da Constituição de Weimar, de 1919, dispunha em seu texto que: "Todos os cidadãos sem distinção contribuem na proporção de seus recursos para todos os encargos públicos segundo os limites da lei” (Cf.: THALMANN, 1988). Nessa perspectiva, por meio do princípio da personificação, passou-se a considerar, na graduação dos tributos, os dados reveladores da capacidade para contribuir com o Estado Social na consecução das suas finalidades institucionais. A destinação do Estado de prover prestações positivas implicou a necessidade de custear essas atividades relevantes para a população (TIPKE; YAMASHITA, 2002, p. 15). 
Nessa visão, o princípio da igualdade em matéria tributária se reduziria à capacidade contributiva (SAINZ DE BUJANDA, 1993, p. 105-106). A personificação, portanto, funciona como o índice de capacidade contributiva dos impostos, admitindo a investigação do patrimônio, da renda e dos serviços do contribuinte (art. 145, $\S 1^{\circ}, C F$ ), inclusive nos impostos reais por meio da patrimonialidade, não se confundindo com a pessoalidade ou personalização, característica dos impostos pessoais (RIBEIRO, 2010, p. 1-25).

A personificação é aplicável a todos os impostos e “[...] permite não só a identificação dos critérios mais proximamente relacionados com a pessoa do contribuinte (pessoalidade), como a renda, mas também aqueles ligados ao seu patrimônio, o que ocorre, predominantemente, nos impostos reais" (RIBEIRO, 2010, p. 1-25). Neste caso, a mensuração do signo de riqueza não abandona a magnitude econômica dos sujeitos, mas sua fórmula aproxima-se de conduta mais relacionada ao patrimônio.

Nessa trilha, o STF reconheceu, em 2013, à luz do princípio da capacidade contributiva por meio da patrimonialidade, a possibilidade de instituição de alíquotas progressivas no ITCD ${ }^{27}$; superando o entendimento antes dominante de que "[...] inexiste espaço de liberdade decisória para o Congresso Nacional, em tema de progressividade tributária, instituir alíquotas progressivas em situações não autorizadas pelo texto da Constituição"28.

A trajetória desses princípios, então, do ponto de vista da igualdade, é relativamente positiva, pois se concebeu, finalmente, a capacidade contributiva como introdução expressa pelo constituinte originário do princípio da igualdade material tributária ${ }^{29}$. E essa concepção teve, ao menos, força para outorgar validade à progressividade nos impostos reais sem previsão constitucional expressa.

\subsubsection{Princípio da equivalência}

27 BRASIL, Supremo Tribunal Federal. RE n. 562.045/RS, Pleno. Min. Relator Ricardo Lewandowaski, Min. Redatora do acórdão Carmen Lúcia. In: DJe n. 233, de 27.11.2013.

${ }_{28}$ BRASIL, Supremo Tribunal Federal. ADI 2.010/DF, Pleno. Min. Relator Celso de Mello. In: DJ de 12.04.2002, p. 51.

29 BRASIL, Supremo Tribunal Federal. RE n. 562.045/RS, Pleno. Min. Relator Ricardo Lewandowski, Min. Redatora do acórdão Carmen Lúcia. In: DJe n. 233, de 27.11.2013, p. 44. 
Dentro dos paradigmas de Estado, como ensina Ricardo Lodi Ribeiro, no Estado liberal, a ideia de igualdade correspondia à de justiça comutativa, baseada no princípio do custo-benefício (ou princípio da equivalência - TIPKE; YAMASHITA, 2002, p. 68), conforme a teoria do benefício de Adam Smith (RIBEIRO, 2010, p. 1-25). Victor Uckmar (2002, p. 16) explica que eram quatro as regras básicas de Adam Smith para a estrutura fundamental dos ordenamentos tributários:

1) Os sujeitos de cada Estado deveriam contribuir e apoiar o governo da maneira mais adequada possível em proporção a suas respectivas capacidades;

2) O imposto que deve pagar cada indivíduo deve ser certo e não arbitrário;

3) Todos os impostos devem ser cobrados no momento e na forma que pareça mais conveniente para que o contribuinte os pague;

4) Todos os impostos deveriam ser concebidos para retirar menos possível do bolso das pessoas.

Roque Antônio Carraza diz haver facultatividade ao legislador em relação à observação da capacidade contributiva na instituição das contribuições de melhoria (CARRAZA, 2008, p. 86). Andrei Velloso (2010, p. 200) entende que à semelhança das taxas, o princípio da igualdade incide à luz do critério do benefício econômico, atuando este como pressuposto para instituição das contribuições de melhoria, que não se confunde com a capacidade contributiva. Discorda-se dessas visões, tendo em vista que a capacidade contributiva, em maior ou menor grau, atinge a todos os tributos. $\mathrm{Na}$ hipótese, o princípio atua, principalmente, para imunizar a indisponibilidade de recursos para recolher tributos.

O STF entendeu pela constitucionalidade da taxa de fiscalização dos mercados e títulos e valores mobiliários (taxa da CVM), ao julgar válida a variação desse tributo em função do patrimônio líquido da empresa. Partiu-se da presunção que esse patrimônio traduziria o volume das operações da empresa na Bolsa ${ }^{30}$. Nessa senda, foi pacificada a noção de que a incorporação de elementos típicos de impostos na base de cálculo das taxas enseja a quebra da uniformidade na aferição do montante devido, mas propicia a graduação conforme a capacidade econômica ${ }^{31}$.

\footnotetext{
30 BRASIL, Supremo Tribunal Federal. RE n. 177.835-1/PE, Pleno. Min. Relator Carlos Velloso. Pleno. Julgado em 22.04.1999. In: DJ de 24.05.2001, p. 762-797.

$31 \quad C f .:$ BRASIL, Supremo Tribunal Federal. RE n. 232.393/SP, Pleno. Min. Relator Carlos Velloso. In: DJ de 05.04.2002; BRASIL, Supremo Tribunal Federal. RE n. 576.321-QO/SP, Pleno. Min. Relator Ricardo Lewandowski. In: DJe de 13.02.2009.
} 
4 HIPÓTESE DE TRABALHO: DESAFIO DE HARMONIZAÇÃO DA IMPOSIÇÃO DE EFETIVIDADE ÀS NORMAS CONSTITUCIONAIS COM A LIBERDADE DEMOCRÁTICA DO LEGISLADOR

A tributação apresenta duas funções primárias: (1) determinar quanto dos recursos da sociedade irá para o controle estatal; e (2) estabelecer como o produto social será compartilhado entre pessoas diferentes, tanto na forma da propriedade privada quanto na de comodidades públicas (MURPHY; NAGEL, 2002, p. 76).

A distribuição do peso fiscal dentro da sociedade brasileira deriva das operações que formam a estrutura social no Brasil. Como dizia Luhmann, reverberado por Raffaele De Giorgi (2011, p. 9-12), "tudo começa com o que já foi começado" - a sociedade, como universo da comunicação social, constitui resultado de si mesma e produz somente sociedade. Ela é, então, “[...] a estrutura de uma ordem autossubstitutiva da seletividade de suas operações".

O programa do Estado Democrático de Direito propõe a reformulação da maneira pela qual os recursos públicos são arrecadados e gastos, tendo, de um lado, por sustentáculo, a capacidade contributiva e, de outro, a gestão fiscal responsável (art. 14 da LC n. 101/2000). Essa agenda programática traz consigo ações que a operacionaliza; e a transformação delas em realidade depende de seleção. A seleção é feita dentre as possibilidades, que cria a realidade como experiência da contingência (DE GIORGI, 2011, p. 9-12) e, ao mesmo tempo, germina novas possibilidades cuja pré-visualização poderia transbordar as fronteiras cognitivas humanas.

A Constituição de 1988, em relação à capacidade contributiva, traz uma mensagem - a da graduação dos impostos que, sempre que possível, será feita segundo a capacidade econômica dos sujeitos (art. $145, \S 1^{\circ}$ ). A locução "sempre que possível” parece ser a parte mais importante do comando; ela faz uma concessão à realidade, para adoção de soluções do tipo second best (que, por exemplo, equilibrem eficiência e equidade), mas veda arbitrariedades. Como decorrência do próprio significado que se dá à palavra, se alguma ação deve ser feita sempre que possível, ela é regra - é um caminho que comporta exceções (justificativas) fundadas na impossibilidade de se seguir a regra. O $\$ 1^{\circ}$ do art. 145 não é exortação de esperança na boa vontade do legislador ordinário; como norma superior, é parâmetro para avaliação da coerência do sistema. 
As decisões de política tributária envolvem largas incertezas empíricas sobre as respectivas consequências econômicas. O futuro se manifesta num horizonte do "não saber", de risco (DE GIORGI, 2011, p. 9-12); e, o tempo (fluxo unidirecional) torna indecifrável a contingência vindoura com base nas experiências do passado. As operações do sistema econômico detêm prevalência de características cognitivas e integram estruturas bem distintas das do Direito.

A doutrina jurídica é compreendida como a formulação da autorreferência do Direito. O Direito é sistema que está dentro da sociedade; "não é política, não é economia, não é religião, nem educação. Não produz obras de arte, não cura doenças, nem distribui notícias" (LUHMANN, 2005, p. 72-79). Como já visto, o Direito existe para resolver problema da defraudação de expectativas e servir à reprodução autopoiética do sistema. A observação e a descrição jurídico-teórica do sistema jurídico pressupõem obrigatoriamente a aceitação do código pelo qual ele opera. Não se pode proceder sobre a base de uma tautologia (a justiça é o que é justo), nem de um paradoxo (o que é justo é o que é injusto). Sendo insuficiente a perspectiva meramente individual para aferir a justiça do sistema jurídico tributário, na via judicial, a injustiça ou a imoralidade do Estado em matéria tributária é considerada se houver ofensa aos direitos fundamentais (TIPKE, 2012, p. 114-118).

A posição dos tribunais no sistema jurídico é determinada pela distinção entre legislação e jurisdição, tornando-se possível incluir os fundamentos da vigência do Direito no próprio sistema jurídico na forma de uma lei constitucional (LUHMANN, 1990, p. 149-168). O Judiciário, que trabalha com complexidade e alternativas riquíssimas (mas limitadas), edita decisões que constituem Direito. Portanto, o juiz, que na concepção clássica seria a "boca da lei”, não conseguiu sê-la, tendo o Judiciário superado, com a sua vinculação à lei, o status de singela autoridade e chegado ao patamar de Poder (DERZI, 2009, p. 50-53).

“Poder", de acordo com Jean-Claude Milner (2002, p. 9), é dispositivo socialmente aceito capaz de criar, modificar e suprimir regras; enquanto "autoridade" apenas faz respeitar as regras que não cria. Luhmann (1985, 122 p.) parte da perspectiva de que poder é concebido como meio de comunicação simbolicamente generalizado, que tem referência sistêmica na sociedade e baseado na reconhecida competência para prescrição de comportamentos. Misabel Derzi (2009, 
p. 51-57), abordando esses dois autores, chancela a diferença que a teoria dos conceitos faz entre os atos dos poderes estatais, ficando o Judiciário a cargo de buscar a justiça na análise individualizada e o Legislativo na missão de fazer justiça para todos. O Judiciário está no centro do sistema jurídico; o Legislativo, na periferia, porque filtra primária e primeiramente os fatos econômicos, políticos e sociais, como se dão no ambiente, para que Executivo e Judiciário trabalhem com eles.

O sistema político tem papel preponderante na realização da justiça fiscal, por ter mais condições, através do seu código binário que detém capacidade cognitiva ampla, de operar a distributividade. $\mathrm{Na}$ esfera tributária, cabe ao legislador tornar as leis mais justas através da seletividade e da progressividade, levando em conta um contexto de complexidade e contingência riquíssimas.

De outro lado, o sistema jurídico é ligado à equivalência porque a decisão judicial opera num contexto de complexidade e contingência já reduzidas pelo processo de positivação do Direito (CAMPILONGO, 2011, p. 103-104). Ao Judiciário é defeso assumir tarefas ínsitas às políticas econômicas, como determinar alíquotas e escolher fatos tributáveis. Num primeiro momento, o Judiciário deve se ater às funções de interpretação do texto, necessária para a superação da ambiguidade prima facie, e de concretização, para suprir a vagueza através do desenvolvimento de um amplo processo seletivo ${ }^{32}$.

Justamente pelo processo de positivação engendrado pela Assembleia Constituinte de 1987, os princípios da igualdade, generalidade, seletividade, progressividade, capacidade contributiva e proporcionalidade passaram a recompor as estruturas do sistema jurídico ${ }^{33}$. Nessa condição, são normas (expectativas contrafáticas), componentes que devem incorporar o funcionamento da jurisdição. E, por ser ponto central do constitucionalismo a pretensão de autofundamentação constitucional do Direito (NEVES, 2013, p. 118), os debates finalmente

32 Ocorre a seletividade do processo de concretização porque leva-se em conta somente os fatos jurídicos relevantes ao enquadramento da hipótese normativa. NEVES, Marcelo. Entre Hidra e Hércules. São Paulo: Editora WMF Martins Fontes, 2013, p. 6-7.

33 Por isso, diz-se que a Constituição de 1988 recompôs os princípios jurídicos relacionados à justiça tributária. Na Constituição de 1946, previa-se que "os tributos terão caráter pessoal sempre que possível, e serão graduados conforme a capacidade econômica do contribuinte". Calcado nesse texto, o constituinte de 1988 complicou a redação nestes termos: "Sempre que possível, os impostos terão caráter pessoal e serão graduados segundo a capacidade econômica do contribuinte". 
encontram terreno fértil para ir além dos limites formais à atuação do legislador e abarcar questões como a coerência (Cf.: ÁVILA, 2003, p. 105-133) e a justiça da carga fiscal.

Longe de se desconsiderar a importância que significou a sistematização da legislação tributária pelo CTN, sabe-se que, no âmbito da reforma constitucional perpetrada pela EC n. 18/1965, o princípio da capacidade contributiva (núcleo da igualdade material tributária) foi revogado expressamente. "Suprimiu-se da Constituição o referencial substancial que servia de fundamento à tributação, para torná-la algo autodenominado de racional, mas que, na prática, mostrou-se mera expressão do exercício de poder" (GRECO, 2011, p. 9-18).

A Constituição de 1988, nesse contexto de revitalização da democracia e da justiça material, não constitui sonho/mito ${ }^{34}$, mas apresenta-se como documento que esboça o projeto de vida da sociedade (LORENZETTI, 1998, p. 253) e ordem geral objetiva do complexo de relações da vida, revelando as ideias morais, políticas e sociais de cunho fundamental para a sociedade numa relação de espaço e tempo, e procurando construir o futuro com base na natureza singular do presente (HESSE, 1991, p. 13-20).

A jurisprudência dos tribunais superiores tem atribuído pouca força deôntica aos princípios constitucionais derivados da justiça tributária em geral, mesmo em sede de juízos negativos de exclusão ${ }^{35}$. Por ora, ainda é incipiente o controle de constitucionalidade das situações em que a capacidade contributiva não é adequadamente captada, apresentando o STF apenas precedentes relativos à proibição do confisco.

\footnotetext{
$34 \quad$ "O mito é forma específica de manifestação do ideológico no plano do discurso". Para Eros Roberto Grau (2015, p. 40-42), mítica foi a Constituição Mexicana de 1917, que criou uma séries de princípios aplicáveis ao trabalho e à previdência social sem institucionalizá-los. Na visão deste trabalho, os princípios constitucionais atrelados à ideia de justiça tributária não são classificáveis como normas programáticas (ou seja, não apresentam eficácia meramente mediata).
}

35 Curiosamente, exemplificando essa insuficiência do atual comportamento judiciário, o sistema político, em caso recente, reformou legislação (LC n. 123/2006), acatando reivindicação de vários setores econômicos em nome da isonomia, da racionalidade e da justiça tributária, que havia sido reputada pelo Judiciário e pela Procuradoria Geral da República como válida, justificada e até recomendável. Cf.: ÁVILA, Humberto. Teoria da Igualdade Tributária. 2. ed. São Paulo: Malheiros, 2009, p. 180-181; BRASIL, Supremo Tribunal Federal. ADI n. 1.643/DF, Pleno. Min. Relator Maurício Corrêa. In: DJ de 14.03.2003; BRASIL, Procuradoria Geral da República. Parecer n. 1.931/AsJConst/SAJ/PGR, na ADI n. 4.860/DF. Disponível em: <http://www.stf.jus.br/portal/processo/verProcessoPeca.asp?id=4238648\&tipoApp=.pdf >. Acesso em: 12 jul. 2014. 
A tese do legislador negativo domina a prática do STF, assumindo que a sua "condição institucional" não o autorizaria a estender os benefícios de uma lei ${ }^{36}$ (muitas vezes sem sequer examinar a validade do critério de distinção ventilado pela legislação - RE n. 409.667/PE ${ }^{37}$ ) ou blindando as situações submetidas de mergulhos analíticos sob a alegação de que "na interpretação e aplicação do princípio da igualdade, há que se confiar ao legislador uma confiável margem de configuração" (Cf.: SIMON, 1996, p. 856) ${ }^{38}$.

A relação entre os sistemas jurídico e político é de dupla contingência. No processo de comunicação, o intérprete-aplicador atribui sentido à mensagem (de conteúdo informativo) do legislador (indaga-se o que o produtor da norma jurídica quis dizer com aquela mensagem), em relação de alteridade (o legislador como alter e a intérprete como ego) consistente em mensagem, informação e compreensão (NEVES, 2013, p. 8-10).

A autonomia do sistema jurídico projeta circularidade entre as categorias normativas. Os princípios funcionam como mecanismos reflexivos em relação às regras, fortificando a capacidade de reprodução adequada do sistema jurídico. "Eles podem servir ao balizamento, à construção, ao desenvolvimento, à fortificação ou ao enfraquecimento, à restrição ou ampliação do conteúdo das regras" (NEVES, 2013, p. 130-134).

Por isso, para dar consequência à violação da igualdade e, com isso, não substituir a capacidade de iniciativa do Legislativo e Executivo, entende-se que é necessária a formulação de novas técnicas de decisão, aplicando soluções jurídicas personalizadas (sensíveis às peculiaridades) aos casos submetidos. Na visão deste trabalho, o problema do Judiciário nessa temática tem sido a falta de disposição para inovar (criatividade) a metodologia da jurisdição no escopo de atribuir efetividade à Constituição. A tarefa de aplicar lidar os princípios tributários que constituem aspectos parciais de justiça não é simplória e nem parece ter um roteiro prédefinido. A vedação do Judiciário de atuar como legislador positivo, porém, nada tem a ver com a criação de normas (é característico dos poderes tomarem decisões que constituem Direito), e

\footnotetext{
36 BRASIL, Supremo Tribunal Federal. RE n. 178.932/SP, Segunda Turma. Min. Relator Celso de Mello. In: DJ de 07.04.1995.

37 BRASIL, Supremo Tribunal Federal. RE n. 409.667/PE. Min. Relatora Ellen Gracie (decisão monocrática). In: Dje de 04.02.2010.

38 BRASIL, Supremo Tribunal Federal. RE n. 405.579/PR, Pleno. Ministro Relator Joaquim Barbosa. In: DJe n. 149 de 04.08.2011.
} 
sim com a contenção para que este não decida com base nos códigos do sistema político e corrompa com as diferenças funcionais de cada subsistema. "Não se pode resolver juridicamente problemas que são do sistema político ou do sistema econômico. A solução jurídica será sempre jurídica, dada a cegueira e a inacessibilidade do sistema jurídico aos códigos dos demais sistemas" (CAMPILONGO, 2011, p. 105).

\section{CONCLUSÕES}

O sistema político é próximo da justiça distributiva porque esta exige operar a igualdade proporcional no tratamento de uma pluralidade de pessoas desiguais. Por outro lado, o sistema jurídico é familiarizado com a justiça comutativa porque o parâmetro (o Direito) já foi positivado por decisão política, bastando retificar suas dimensões subjetivas e fazer equivaler o tratamento a pessoas que estão em patamar de igualdade.

A Constituição pode ser violada em sua supremacia tanto por meio de ações quanto por intermédio de omissões. O ferimento da Constituição através de conduta positiva dá-se no plano da validade. As omissões, por sua vez, afrontam a Constituição no plano da eficácia. À luz dessa diferença, as regras de decisão que corrigem esses dois tipos de estiolamentos devem ser distintas.

As ações legislativas inconstitucionais que criam desigualações incoerentes, irracionais, arbitrárias e infundadas são processadas pelo sistema jurídico com a declaração de nulidade. No entanto, as omissões inconstitucionais são questões um pouco mais complexas, sendo mais coerente, em muitas situações, o restabelecimento do estado de constitucionalidade sem o recurso do pronunciamento de nulidade. Dentre as fórmulas de correção jurisdicional de desigualdades legislativas inconstitucionais, tem-se proposto que o Judiciário, através de instrumentos de condicionamento cronológico da inconstitucionalidade, faça a qualificação da inércia legislativa e atribui-lhe a consequência adequada: (a) quando a concretização constitucional demanda construção política, a norma injusta até então vigente perde vigência se o Legislativo, ciente da sua omissão, não produzir regramento válido no prazo terminativo; (b) 
quando a concretização constitucional pode ser operada pelo sistema jurídico, a norma injusta é corrigida em seu sentido constitucional (tornada inteira, suficiente - Cf.: ZAGREBELSKY, 1977, 392 p.) se o Legislativo, ciente de seu equívoco, não quiser dispor de forma diferente em prazo suspensivo ( $C f$. FERNANDES, 2014, 183 f.).

Enfim, a justiça fiscal é ideário a ser perfilhado pelos subsistemas sociais. A Constituição torna jurídica a relação (historicamente de poder) entre o fisco e o contribuinte e, por isso mesmo, o Judiciário tem o papel de fiscalizar a atuação dos poderes constituídos.

\section{REFERÊNCIAS}

ABBOUD, Georges; CARNIO, Henrique Garballini; OLIVEIRA, Rafael Tomaz de. Introdução à teoria e à filosofia do Direito. São Paulo: Revista dos Tribunais, 2013.

ALEXY, Robert. La institucionalización de la justicia. Tradução de José Antonio Seoane, Eduardo Roberto Sodero e Pablo Rodrigues. 2. ed. Granada: Comares, 2010.

ALEXY, Robert. Teoria dos direitos fundamentais. Tradução de Virgílio Afonso da Silva. São Paulo: Malheiros, 2008.

ANDRADE, José Carlos Vieira. Os Direitos Fundamentais na Constituição da República Portuguesa de 1976. Coimbra: Livraria Almedina, 1987.

ÁVILA, Humberto Bergmann. Moralidade, razoabilidade e eficiência na atividade administrativa. Revista Brasileira de Direito Público RBDP, v.1, n.1, p. 105-133, abr./jun. 2003.

ATALIBA, Geraldo. Hipótese de incidência tributária. São Paulo: Revista dos Tribunais, 1973, p. 45-125.

BARBOSA, Rui. Oração aos moços. Rio de Janeiro: Ediouro, 1997.

BOBBIO, Norberto. Igualdade e liberdade. Tradução de Carlos Nelson Coutinho. Rio de Janeiro: Ediouro, 1996.

CABETTE, Eduardo Luiz Santos.Ética, moral e direito: uma abordagem sobre a delação premiada no sistema penal brasileiro. Direito \& Paz, Americana, v. 3, n. 5, pp. 31-41, dez. 2001.

CAMPILONGO, Celso Fernandes. Política, sistema jurídico e decisão judicial. 2. ed. São Paulo: Saraiva, 2011. 
CARRAZA, Roque Antônio. Curso de Direito Constitucional Tributário, 24. ed. São Paulo: Malheiros Editores, 2008.

CARVALHO JÚNIOR, Pedro Humberto Bruno de. As discussões sobre a regulamentação do Imposto sobre Grandes Fortunas: a situação no Brasil e a experiência internacional. Rio de Janeiro: IPEA, out. 2011.

COMPARATO, Fábio Konder. Igualdade, Desigualdades. Revista Trimestral de Direito Público, São Paulo, n. 1, pp. 69-78, 1993.

DAUDE, Christian; GUTIÉRREZ, Hamlet; MELGUIZO, Ángel. What drives tax morale? Review of Public Economics/Hacienda Pública Española, Madrid, n. 207, pp. 11-26, 2013.

DE GIORGI, Raffaele. A administração pública na sociedade complexa. RDA - Revista de Direito Administrativo, Rio de Janeiro, v. 256, pp. 9-12, jan./abr. 2011.

DERZI, Misabel Abreu Machado. Modificações da Jurisprudência no Direito Tributário: proteção da confiança, boa-fé objetiva e irretroatividade como limitações constitucionais ao poder de tributar. São Paulo: Noeses, 2009.

DERZI, Misabel Abreu Machado. Direito tributário, Direito Penal e Tipo. São Paulo: Ed. Revista dos Tribunais, 1988, 398 p.

FAMA, Eugene F.; FRENCH, Kenneth R. Taxes, Financing decisions, and Firm value. The Journal of Finance. Vol III, n. 3, jun. 1998.

FARIA, José Eduardo; CAMPILONGO, Celso Fernandes. A Sociologia Jurídica no Brasil. Porto Alegre: Sergio Antonio Fabris Editor, 1991.

FERNANDES, Rayneider Brunelli de Oliveira. Controle da extrafiscalidade à luz da igualdade: limitações ao poder de desonerar e soluções jurisdicionais para correção de situações anti-isonômicas. Dissertação (mestrado) - Universidade Federal de Uberlândia, Programa de Pós-Graduação em Direito. 2014. 183 f.

FERRAZ JÚNIOR, Tércio Sampaio. Direito, retórica e comunicação: subsídios para uma pragmática do discurso jurídico. São Paulo: Saraiva, 1973. 205 p.

GRAU, Eros Roberto. A ordem econômica na Constituição de 1988 (Intepretação e Crítica). 17. ed. São Paulo: Malheiros, 2015.

GRECO, Marco Aurélio. Contribuições (uma figura “sui generis”). São Paulo: Dialética, 2000.

GRECO, Marco Aurélio. Crise do Formalismo no Direito Tributário Brasileiro. Revista da PGFN - Procuradoria Geral da Fazenda Nacional, p. 9-18, v.1. n.1. jan./jun. 2011. Brasília: Procuradoria Geral da Fazenda Nacional, 2011.

GUSTIN, Miracy Barbosa; DIAS, Maria Tereza Fonseca. (Re)pensando a pesquisa jurídica. 4. ed. Belo Horizonte: Del Rey, 2013. 
HESSE, Konrad. A força normativa da Constituição. Tradução e notas de Gilmar Ferreira Mendes. Porto Alegre: Fabris Ed., 1991.

HOLMES, Stephen; SUNSTEIN, Cass R. The cost of rights: Why liberty depends on taxes. New York: W. W. Norton \& Company, 2000.

LAKATOS, Eva Maria; MARCONI, Marina de Andrade. Metodologia do trabalho científico: procedimentos básicos, pesquisa bibliográfica, projeto e relatório, publicações e trabalhos científicos. 4. ed. São Paulo: Atlas, 1992.

LARENZ, Karl. Metodologia da Ciência do Direito, 3. ed. Lisboa: Fundação Calouste Gulbekian, 1997, p. 490.

LAVINAS, Lena; MOELLMANN FERRO, Thiago Andrade. A long way from tax justice: the Brazilian case. Global Labour University working paper, Geneva, n. 22, pp. 1-35, 2014.

LIPOVESTKY, Gilles. El crepúsculo del deber. La ética indolora de los nuevos tiempos democráticos. Tradução de Juana Bignozzi. Barcelona: Editorial Anagrama, 1994.

LOCKE, John. Dois tratados sobre o governo. Tradução de Júlio Fischer. São Paulo: Martins Fontes, 2001.

LORENZETTI, Ricardo Luís. Fundamentos de Direito Privado. São Paulo: Revista dos Tribunais, 1998, p. 253.

LUHMANN, Niklas. A posição dos tribunais no sistema jurídico. Tradução de Peter Naumann e revisão de Vera Jacob de Fradera. Revista Ajuris, Porto Alegre, v. 17, n. 49, p. 149-168, jul. 1990.

LUHMANN, Niklas. Complexidad y modernidad: de la unidad a la diferencia. Tradução e edição de Josetxo Berian e José María García Blanco. Madrid: Editorial Trotta, 1998.

LUHMANN, Niklas. El derecho como sistema social. In: DIEZ, Carlos Cómez-Jara (Ed.). Teoría de sistemas y derecho penal: fundamentos y posibilidades de aplicación. Granada: Comares, 2005.

LUHMANN, Niklas. Introdução à teoria dos sistemas: aulas publicadas por Javier Torres Nafarrate. Tradução de Ana Cristina Arantes Nasser. Petrópolis: Vozes, 2009.

LUHMAnN, Niklas. Poder. Tradução de Martine Creuzot de Rezende Martins. Brasília: Ed. Universidade de Brasília, 1985.

MACHADO, Hugo de Brito. Curso de Direito Tributário. 24. ed. São Paulo: Malheiros, 2004.

MARINS, James. Justiça tributária e processo tributário: ensaios. Curitiba: Champagnat, 1998.

MARTINELLI, Mário Eduardo. A deterioração dos direitos de igualdade material no neoliberalismo. Campinas: Millennium Editora, 2009. 
MARTINS, Fernando Rodrigues. Controle do patrimônio público. 5. ed. rev., ampl. e atual. São Paulo: Ed. Revista dos Tribunais, 2013.

MELO, José Eduardo Soares de. IPI: teoria e prática. São Paulo: Malheiros, 2009.

MERON, Theodor. International Law in the age of human rights. General Course on Public International Law. Hague Academy of International Law. Leiden/Boston: Martinus Njhoff Publishers, 2004.

MILNER, Jean-Claude. Les Puvoirs: d'un Modèle à l'Autre. Revué Élucidation, Paris, n. 6/7, p. 9, 2002.

MIRANDA, Jorge. Direitos fundamentais e ordem social (na Constituição de 1933). Revista da Faculdade de Direito da Universidade de Lisboa, v. 46, n. 1, 2005.

MURPHY, Liam; NAGEL, Thomas. The myth of ownership: taxes and justice. New York: Oxford University Press, 2002.

NABAIS, José Casalta. A face oculta dos direitos fundamentais: os deveres e os custos dos direitos. Revista de Direito Público da Economia, Belo Horizonte, v. 5, n. 20, p.1-24, out. 2007.

NALINI, José Renato. Ética geral e profissional. 7. ed. rev., atual. e ampl. São Paulo: Editora Revista dos Tribunais, 2009.

NEVES, Clarissa Baeta; SAMIOS, Eva M. B. A nova teoria dos sistemas. Porto Alegre: Universidade/UFRGS Goethe Institut - ICBA, 1997.

NEVES, Marcelo. Entre Hidra e Hércules. São Paulo: Editora WMF Martins Fontes, 2013.

ORTEGA y GASSET, José. Pidiendo una biblioteca. El imparcial, Madrid, v. I, p. 82, 21.02.1908.

PERELMAN, Chaïm. Ética e Direito. Tradução de Maria Ermantina de Almeida Galvão. 2. ed. São Paulo: Martins Fontes, 2005.

REZENDE, Fernando. O Processo da Reforma Tributária. Texto para discussão n. 396. Brasília: IPEA, 1996.

RIBEIRO, Ricardo Lodi. O Princípio da Capacidade Contributiva nos Impostos, nas Taxas e nas Contribuições Parafiscais. RFD - Revista da Faculdade de Direito da UERJ, Rio de Janeiro, v. 1, n. 18, p. 1-25, 2010.

ROCHA, Altamirando Pereira da; FERNANDES, Rayneider Brunelli de Oliveira. Justiça tributária nos impostos indiretos e aplicabilidade judicial. Revista Fórum de Direito Tributário - RFDT, v. 13, p. 107-125, 2015.

ROCHA, Sônia. O impacto distributivo do imposto de renda sobre a desigualdade de renda das famílias. Pesquisa e Planejamento Econômico, Rio de Janeiro, n. 32, v. 1, pp. 73-105, abr. 2002. 
SÁINZ DE BUJANDA, Fernando. Leciones de Derecho Financiero. 10. ed. Madrid: Ed. Universidad Complutense, 1993.

SÁINZ DE BUJANDA, Fernando. Teoría de la educación tributaria. Madrid: LAEL, 1967.

SARLET, Ingo; MARINONI, Luiz Guilherme; MITIDIERO, Daniel. Curso de direito constitucional. São Paulo: Ed. Revista dos Tribunais, 2012.

SHAPIRO, Ian; GRAETZ, Michael J. Death by a Thousand Cuts: The Fight over Taxing Inherited Wealth. Princeton: Princeton University Press, 2005.

SIMON, Helmut. La Jurisdicción Constitucional. In: BENDA, Ernst et al. Manual de Derecho Constitucional. Madrid: IVAP; Marcial Pons, 1996.

SOARES, Maria Victória. Cidadania e Direitos Humanos. In: CARVALHO, José Sérgio Fonseca de (org.). Educação, cidadania e direitos humanos. Petrópolis: Vozes, 2004.

SOUZA, Celina. Federalismo, desenho constitucional e instituições federativas no Brasil pós1988. Revista de Sociologia Política, Curitiba, n. 24, p. 105-121, jun. 2005.

TANZI, Vito. Tax Reform in Latin America: a long term assessment. XXV Regional Seminar on Fiscal Policy, CELAC, Santiago (Chile), mar. 2013.

TEIXEIRA, J.F. On Chalmer's Theory of Consciousness. Psicologia USP, São Paulo, v.8, n.2, p.109-128, 1997.

TEUBNER, Günther. O Direito como Sistema Autopoiético. Lisboa: Fundação Calouste Gulbenkian. Tradução de José Engrácia Antunes, 1989.

THALMANN, Rita. A República de Weimar. Rio de Janeiro: Jorge Zahar, 1988.

TIPKE, Klaus. Moral tributária do Estado e dos contribuintes. Tradução de Luiz Dória Furquim. Porto Alegre: Fabris, 2012.

TIPKE, Klaus; YAMASHITA, Douglas. Justiça Fiscal e Princípio da capacidade contributiva. São Paulo: Malheiros, 2002.

TORRES, Ricardo Lobo Torres. O Princípio da Tipicidade no Direito Tributário. Revista Eletrônica de Direito Administrativo Econômico, Salvador, Instituto de Direito Público da Bahia, n. 5, fev./mar./abr. de 2006, p. 8. Disponível: <www.direitodoestado.com.br>. Acesso em 29 jul. 2013.

TORRES, Ricardo Lobo. Normas gerais antielisivas. Revista Fórum de Direito Tributário, n. 1, Belo Horizonte, pp. 90-123, 2003.

TORRES, Ricardo Lobo. Curso de Direito Financeiro e Tributário. 16. ed. Rio de Janeiro: Renovar, 2009.

TORRES, Ricardo Lobo. O IPI e o princípio da seletividade. Revista Dialética de Direito Tributário, n. 18, p. 94-102, mar/1997. 
UCKMAR, Victor. El principio de la equidad tributaria y el vínculo de solidaridad social: la relación entre las necesidades. La Capacidad Contributiva, Pressupuesto Jurídico y Fundamento de la Tributación. Conferencia Técnica del CIAT Taomina 2000. Madrid: Ed. Instituto de Estudios Fiscales, 2002.

UCKMAR, Victor. Princípios comuns de direito constitucional tributário. Tradução de Marco Aurélio Greco. São Paulo: Malheiros, 1999.

WYNIA, Gary W. The politics of Latin American development. Cambridge, London, New York, Melbourne: Cambridge University Press, 1978.

XAVIER, Alberto Pinheiro. Os princípios da legalidade e da tipicidade da tributação. São Paulo: Revista dos Tribunais, 1978, p. 92.

ZAGREBELSKY, Gustavo. La giustizia costituzionale. Bologna: Il Mulino, 1977.

ZOCKUN, Maria Helena (coord.). Simplificando o Brasil: Propostas de reforma econômica do governo com o setor privado. Texto para discussão n. 3. São Paulo: FIPE, mar. 2007. 